\title{
Plant derived bioactive compounds as potential inhibitors of ZIKA virus: an in silico investigation
}

\author{
Sheikh Rashel Ahmed ${ }^{1,2, \&, *}$, Anik Banik ${ }^{1, \&}$, Sadia Mahjabin Anni ${ }^{1,2}$, Mohammed \\ Mehadi Hassan Chowdhury ${ }^{3}$
}

${ }^{1}$ Faculty of Biotechnology and Genetic Engineering, Sylhet Agricultural University, Sylhet3100, Bangladesh

${ }^{2}$ Department of Plant and Environmental Biotechnology, Sylhet Agricultural University, Sylhet3100, Bangladesh

${ }^{3}$ Department of Microbiology, Faculty of Science, Noakhali Science and Technology University, Noakhali-3814, Bangladesh

${ }^{\&}$ Authors contributed equally to this work

Abbreviations: ZIKV, ZIKA virus; LD $_{50}$, Lethal dose 50; ADME, Absorption, distribution, metabolism, and excretion; BBB, Blood brain barrier.

\section{*Corresponding author:}

Sheikh Rashel Ahmed

Department of Plant and Environmental Biotechnology

Faculty of Biotechnology and Genetic Engineering

Sylhet Agricultural University, Sylhet-3100, Bangladesh.

E-mail: rashel.peb@sau.ac.bd 


\begin{abstract}
The ZIKA virus has caused a heavy concern everywhere the globe because of its high infectivity and mortality rate. Still, there's no specific drug or preventive medication to treat ZIKA infection despite comprehensive analysis by the researchers. This study was designed to demonstrate the efficacy of some plant derived bioactive compounds against ZIKV by using both structure and ligand based virtual screening methods. A number of 35 plant metabolites were screened against ZIKA NS2B-NS3 protease (5LC0), Envelop protein (5JHM), Capsid protein (5YGH) and NS5 RNA-dependent RNA polymerase protein (5U04) employing molecular docking approach. Results showed that there have been four metabolites, i.e. Chicoric acid, Luteone, Reserpine and Rosmarinic acid provide highest binding affinity to targeted ZIKV proteins. Crucial binding sites and drug surface hotspots are unraveled for every targeted viral protein. The ADME study showed that neither of the candidate compounds had side effects that would reduce their druglike properties. As compared, the toxicity pattern analysis has unmasked the non-toxic essence of top drug candidates. The RMSD values of ligand-macromolecule complexes were $2 \AA$ apart from Envelop protein- Chicoric Acid, although the RMSF values showed normal atomic fluctuations within the molecular dynamics analysis, with the exception of Envelop protein- Chicoric Acid. The expected majority of the target class the highest drug candidates is enzyme classes (e.g. protease, hydrolase, phosphatase). In addition, the drug similarity prediction revealed several structural analogs from drugbank such as Isoformononetin (DB04202), Deserpidine (DB01089) and Rescinnamine (DB01180) etc. and these analogs could even be an option for the treatment of ZIKV infections. The study can pave the way for the creation of effective ZIKV medications and preventive measures. We highly recommend further in vivo trials for the experimental validation of our findings.
\end{abstract}

\title{
Keywords
}

ZIKA Virus, Plant Metabolites, Molecular Docking, Molecular Dynamics, ADME. 


\section{Introduction}

The Zika virus (ZIKV) belongs to the Flaviviridae family of positive-stranded RNA viruses. In 1947, during experiments on the ecology of yellow fever, ZIKV was first isolated in Uganda from a febrile sentinel monkey by the Rockefeller Foundation (Dick et al., 1952). ZIKV is an arthropod-borne virus that is carried by mosquito vectors and can affect both human and moderately non-human primates extensively (Buechler et al., 2017 and Dick et al., 1952). In Nigeria (Africa), the first ZIKV infection in human is ever reported (Macnarmara, 1954). The first non-African ZIKV strain 'P6-740’ was isolated in 1966 in Malaysia (Marchette et al., 1969). During an analysis in Brazil, the fatality rate in the case of microcephaly and other severe. The advent of ZIKV was linked with neurological problems such as Guillain-Barré syndrome (GBS) in adults from French Polynesia and microcephaly in neonates from Brazil (Krauer et al., 2017). After ZIKV infection, symptoms appear to develop after an incubation time of 3 to 12 days in symptomatic cases and are reported to be characterized by fever, headaches, rashes, arthralgia, gastrointestinal disease, conjunctivitis, myalgia etc. (Duffy et al., 2009 and Oehler et al., 2014). However, there is no particular therapy, antiviral treatment or vaccine is available for ZIKV infection till now. A variety of possible therapies are being evaluated by researchers (Barrows et al., 2016). However, all of the signs caused for ZIKV infection are treated now, likewise acetaminophen-based treatments for fever and discomfort, an antihistamine for pruritic rash, and fluid consumption (WHO, 2018). Scientific groups, however, are trying to implement effective treatment strategies or to develop effective ZIKA virus drugs. A hope is showing by a FDA approved drug for Hepatitis C named Sofosbuvir that inhibits ZIKV replication targeting virus's ribonucleic acid, have significantly revealed their anti-viral efficacy in in-vivo trials and a step ahead towards clinical trials (Bullard-Feibelman et al., 2017 and Mumtaz et al., 2017). As a novel drug or vaccine development needs time while alternatively, medicinal plants could be used as early as possible in the manufacture of medicines. The importance of plants due to their medicinal benefit and therapeutic applications as ancient medicines has been documented by many scientific researchers (Azim et al., 2020; Koc et al., 2015; Banik et al., 2020 and Ahmed et al., 2019). Herbal bio-active compounds such as curcumin, a food supplement, have an antiviral activity against the Zika virus (Mounce et al., 2017). Recently, a study found structurally related 
polyphenols delphinidin (D), and epigallocatechin gallate (EGCG) both have poteintial to impaire infectivity of ZIKV (Vázquez-Calvo et al., 2017). Natural plant based bioactive products has the potential to flourish as the basis of modern holistic health care system (Cheuka et al., 2017). The bioactive compound from medicinal plants has the ability to be effective in curing life-threatening diseases such as cancer, Alzheimer's disease, diabetes, malaria, and heart disease while minimizing the toxicity of medicines (Karimi et al., 2015). Side effects of synthetic products may be bypassed by using of the natural product as a new medication to resist the ZIKV infection and associated complications. Therefore, the purpose of the research was to test some plant-based bio active drug candidate compounds against ZIKV through virtual screening methods and various computational studies (Table 1).

\section{Materials and Method}

\subsection{Extraction of Zika virus proteins/protein-domains and plant metabolites}

ZIKA virus Envelope protein (5JHM), Capsid Protein (5YGH), NS5 RNA-dependent RNA polymerase (5U04), and NS2B-NS3 protease (5LC0) three dimensional (3D) structure were extracted from the RCSB Protein Data Bank (Rose et al., 2016). Pubchem database was used to retrieve a total 35 metabolites belonging to different class (Table 1) in SDF format (Kim et al., 2016). Further the retrieved SDF structures were converted into the PDB format by Open Babel v2.3 (O'Boyle et al., 2011).

\subsection{Evaluation of plant metabolites against Zika virus proteins/protein-domains}

An effective molecular approach is computer-assisted drug design (Morris et al., 2008). It is ideal for screening therapeutics against particular drug targets of deadly pathogens (Meng et al., 2011). This important approach is used to model the relationship between small ligands and macromolecules, giving a potential chance to a ligand in the way for the discovery of drugs (Kitchen et al., 2004). The binding affinity of 35 plant metabolites with different Zika virus proteins/protein domains (drug targets/macromolecules) were determined by using the PatchDock server (Supplimentary File 1). The PatchDock server complies geometry docking using the shape complementary principals and find out the best patch for the lingand including active sites of the macromolecules (Schneidman-Duhovny et al., 2005 and Banik et al., 2020). The clustering RMSD was set 4.0 and the macromolecule-small ligand type was utilized for 
docking purpose. Recently, Pinocembrin a compound from honey has been suggested as a Zika virus replication inhibitor by experimental study (Lee et al., 2019) and used as a positive control for this present study. FireDock refinement tool utilized for refinement purpose of the docked complex (Mashiach et al., 2008 and Banik et al., 2020). The ligand bond complexes were visualized by Discovery Studio v3.1 and PyMOL v2.0 (Wang et al., 2015 and DeLano et al., 2002).

\subsection{Drug surface hotspot analysis and ligand binding pocket prediction}

By analyzing the docked complexes with the top metabolites which was Chicoric acid, Luteone, Reserpine and Rosmarinic acid, the drug surface hotspot of Zika virus proteins was evaluated.using several software like Discovery Studio and PyMOL v.2.0 (Wang et al., 2015; DeLano 2002). The comparative structural analysis was employed by utilizing the binding patterns. Moreover, the molecular interaction of pinocembrin (a positive control) with the studied proteins was also analyzed.

\subsection{Molecular Dynamics Study}

By performing normal mode analysis (NMA) via iMODS server (http:/imods.chaconlab.org), the conformational stability of the ligand-protein complex interactions was evaluated using various properties like deformability and eigen-values of the protein-ligand interactions (López-Blanco et al., 2014). Further the complexes, the root mean square deviation (RMSD), B factor analysis and the root-mean-square fluctuation (RMSF) were measured and analyzed using LARMD server ((http://chemyang.ccnu.edu.cn/ccb/server/LARMD), uses AMBER16 program from the trajectory with a time interval per picosecond (Roe \& Cheatham, 2013; Yang et al., 2019; Banik et al; 2020).

\subsection{Analysis of top metabolite's Drug profile}

The drug levels and kinetics of drug delivery to the tissues within an organism are determined by four key factors which are absorption, distribution, metabolism and excretion (ADME). The pharmacological activity efficacy was influenced by these parameters (Balani et al., 2005). The SwissADME server was utilized to explore the ADME properties of top four screened metabolites (Daina et al., 2017). The toxicity pattern of these top four metabolites was assessed 
by pkCSM server (Pires et al., 2015).This server predicts several toxic parameters like LOAEL, $\mathrm{LD}_{50}$ etc.

\subsection{Prediction of drug targets and available drug molecules from DrugBank}

To estimate the future macromolecular targets of expected drug candidates, an online based sever SwissTargetPrediction was used (Daina et al., 2019; Rahman et al., 2020). Based on a combination of 2D and 3D similarity, the server estimates a library of 3,70000 recognized bioactive compounds on around 3000 proteins. Moreover, on the basis on homology screening of expected top drug candidates, SwissSimilarity web tools were used to identify possible existing drug molecules that can be repurposed against Zika Virus. The server utilized ligand-based virtual screening of several small molecule libraries to use various approaches including electroshape, spectrophores, FP2 fingerprints, and align-ITI to find approved, experimental, or commercially available drugs from DrugBank (Zoete et al., 2016).

\section{Results}

\subsection{Evaluation of plant metabolites against ZIKV}

The retrieved structure of ZIKA virus crucial protein/protein domain (macromolecule) and plant metabolites (ligands) were optimized and placed for molecular docking stimulation to predict the binding affinity between the macromolecules and ligands which were previously mentioned above (Supplementary File 1). The top ranking of metabolite was done on the basis of global binding energy and the fin dings reveals that the top four scorers (metabolites) were the same in terms of minimum binding energy for each of the macromolecules (Table 2 and Figure 2). In each case, Chicoric acid, Luteone, Reserpine, and Rosmarinic acid display the best binding interactions with four studied ZIKA virus macromolecules (Figure 3). Moreover, Luteone exhibited the highest binding affinity with Capsid Protein $(-52.92 \mathrm{kcal} / \mathrm{mol})$, Chicoric acid with Envelope protein $(-58.26 \mathrm{kcal} / \mathrm{mol})$, Reserpine with ZIKA virus NS2B-NS3 protease (61.45 $\mathrm{kcal} / \mathrm{mol}$ ) and finally, Rosmarinic acid shows best binding affinity with NS5 RNA-dependent RNA polymerase protein $(51.26 \mathrm{kcal} / \mathrm{mol})$ (Figure 2). In additionally, these top predicted 4 metabolites shows very similar binding affinity against among targeted four macromolecules (Figure 2 and Table 2). 


\subsection{Analysis of drug surface hotspot and ligand binding pocket prediction}

To unravel the drug surface hotspot of the studied ZIKA proteins, the structural conformation of the docked complex was analyzed. The ligand binding pattern and residues interacting with their respective positions have been investigated (Table 2). Amino acids from 31 to 61 positions were crucial for the binding interactions of ZIKA Capsid protein (5YGH). Where capsid protein Arg32, Ala35, Leu33, Lys31 amino acid was involved in most cases to formed the docked complex with phyto-ligands. The ligands shows better binding affinity for 143-145, 301-303 and 361-374 regions for envelop protein (5JHM) and most dominant amino acids for interactions with the ligands were Leu300,Lys301, Val303, Val364,Ala361, Asn362, Thr366, Val143, Gly 145.The crucial binding sites for ZIKA virus NS2B-NS3 protease (5LC0) remains into the amino acid 1132-1162 region. The Tyr1161, Val1155, Tyr1130, Ala1132 acid binding sites are found maximum times for the docked complexes. The protein amino acid 403-423 regions were identified as top surface hotspots for NS5 RNA-dependent RNA polymerase protein (5U04); among binding residues Ala423, Ala408, Lys403 were found most of the cases.

\subsection{Molecular Dynamics stimulation}

The deformation of the structures was primarily based on the hinges of the structure. The hinges found in the entire structure are not critical and are stable (Figure 4A, 5A, 6A, 7A). The study of the B factor revealed that there were no significant fluctuations, indicating very less loop numbers (Figure 5B, 6B, 7B) except Envelope-Chicoric acid complex (Figure 4B). The Eigen values for the complexes were higher and the structure was compact and it demonstrated its resistance to deformation. The Eigen values $7.60335 \times 10^{-5}$ for Capsid-Luteone complex, $2.769616 \times 10^{-5}$ (Figure 5C) for Envelope-Chicoric acid complex (Figure4C), and comparatively higher 5.563876 x 10-4 for NS2B-NS3 Protease-Reserpine (Figure 6C) and 7.483752 x $10^{-5}$ for NS5 RNA-dependent RNA polymerase protein-Rosmarinic acid complex, respectively (Figure7C). The complex RMSD value for all studied complex was less than $2 \AA$ in studied complexes (Figure 5B, 6B, 7B ) except Envelope-Chicoric acid complex (Figure 4D). The NS5 RNA-dependent RNA polymerase protein-Rosamarinic complex and Capsid-Luteone shows equilibrium state (Figure 5D, 7D). All the structure didn't show any major repulsion. For all the complexes the RMSF values showed a regular pattern of atomic fluctuations during the 
molecular dynamics stimulation (Figure 5E, 6E, 7E) apart from the Envelope-Chicoric acid complex it shows the higher fluctuations may be because of loop region (Figure 4E).

\subsection{ADME analysis of top drug candidates}

In order to test their drug profiles, various ADME properties, i.e. pharmacokinetics, lipophilicity, water solubility, physicochemical parameters, medicinal chemistry were calculated for the top drug candidates (Figure 8 and Table 3). Examination of inhibition results with various isoforms of CYP (CYP2D6, CYP1A2, CYP2C19, CYP2C9, CYP3A4) reveals that among four, only luteone has the potential to associate with any isoforms of P450 cytochromes. GI absorption was found to be higher for Luteone and Reserpine, while chicric acid and rosmarinic acid were found to be lower. In addition, we used the BOILED-Egg model to measure the blood-brain barrier (BBB) permeation, which showed no BBB permeating among the top drug candidates tested. Each candidate was found water soluble (Table 3).

\subsection{Toxicity pattern analysis of top drug candidates}

The toxicity pattern of top screened candidates states four of them were negative to, carcinogenicity, skin sensitization, Eye corrosion, AMES toxicity. While only luteone may responsible for eye irritation. The all candidates were not responsible for hepatotoxicity and $T$. pyriformis toxicity. The $\mathrm{LD}_{50}$ for chicoric acid, luteone, reserpine and rosmarinic acid was 2.445 , 2.504, 2.958 and 2.811, respectively (Table 4).

\subsection{Prediction of drug targets and available drug molecules from DrugBank}

The predicted majority of the target class belonged Aldose reductase, Matrix metalloproteinase, Muopioid receptor, Transthyretin etc. (Figure 9 and Table 5). The ligand structural based virtual screening was performed to predict similar bioactive structural compound from DrugBank. The result shows Reserpine similar to Deserpidine (DB01089), Rescinnamine (DB01180) weith higher score i.e. 0.978, 0.925, respectively. The rosmarinic acid and chicoric acid both has structural similarity with 2-deoxy-3,4-bis-o-[3-(4-hydroxyphenyl)propanoyl]-1-threo-pentaric acid (DB08322). Finally, luteone shows a structural similaraity with antiapoptosis drug i.e. Isoformononetin (DB04202) (Table 6). These similar drugs may also used to fight with ZIKA virus needs further in vivo trials. 


\section{Discussion}

Before its arrival in the Americas in 2015, the ZIKV has infected millions of people. The virus, primarily due to its connection with serious neurological conditions, has triggered social and sanitary warning (Saiz et al., 2017). Despite of extensive research any vaccine or approved drug has not been released to thwart ZIKA virus infection and reduce the mortality (Panwar and Singh, 2018). By being a lead molecule in the production of drug candidates, plant-derived natural products play an essential role. (Joseph et al., 2016). Plants provide a variety of phytochemicals with antioxidant action, such as flavonoids, terpenoids, lignins, alkaloids and coumarins which provide help to repress viral activity. Therapies based on various plant-derived products for human health are associated with less toxicity and minimal side effects (Ghildiyal et al., 2020). Therefore, attempts have been made in the present analysis to test certain plantderived metabolites as ZIKA inhibitory agents on the basis of their binding affinities to the pathogen's several key proteins. In this current investigation, a total of 35 phyto chemicals were tested against four key proteins of the ZIKA virus. The computational biology opens new opportunities and accelerated the drug discovery processes (Hirono 2002). This approach now becomes a core component to discover and develop new lead compounds against many infectious pathogens in the biopharmaceutical industry (Hirono 2002; Ivanov et al., 2006). By this way, the possibilities of binding potential small molecules as ligands / inhibitors can be visualized and save time and cost in the drug development process (Joseph et al., 2016). Plant derived compounds like Luteolin, Quercetin, Baicalein and Kaempferol are potential antiviral agents against a wide range of important viruses including HIV, H5N1 influenza A virus, Dengue virus (DENV), Chikungunya Virus (CHIKV), Japanese encephalitis virus and Coxsackie virus (Habbu et al., 2009). Pinocembrin, a flavanone derived from honey, tea and ruddy wine, is used as a control in present study. It was too appeared that Pinocembrin had broad-spectrum antiviral impacts against ZIKA which is experimentally proved, also shows antiviral activity against DENV2 and CHIKV (Lee et al., 2019).

In this study we evaluate several phyto chemicals against several proteins of ZIKA virus i.e. envelope protein (5JHM), Capsid Protein (5YGH), NS5 RNA-dependent RNA polymerase (5U04), and NS2B-NS3 protease (5LC0) (Dai et al., 2016; Shang et al., 2018; Lei et al., 2016; Godoy et al., 2017). 
The NS5 RNA-dependent RNA polymerase (5U04) and NS2B-NS3 protease (5LC0) are the core protein to remain infective and survive for the ZIKA virus (Lei et al., 2016; Godoy et al., 2017). NS2B / NS3 viral protease, which cleaves the viral polyprotein along with host cell proteases into the individual proteins required for viral replication; the NS5 RNA-dependent RNA polymerase of ZIKA also a crucial need for virus replication (Lei et al., 2016; Godoy et al., 2017). The othe two targeted protein, ZIKV-E (5JHM) contains a unique, positively charged patch, which may influence host attachment and the capsid (5YGH) protein is a multifunctional protein, since it binds to viral RNA in the process of nucleocapsid assembly and plays important roles in virus infection processes by interacting with cellular proteins, modulating cellular metabolism, apoptosis and immune response (Dai et al., 2016; Shang et al., 2018). These characteristics make us to work with these four protein and these are an attractive candidate for drug design. Among the plant derived bio active compounds, luteone exhibited the highest binding affinity with Capsid Protein $(-52.92 \mathrm{kcal} / \mathrm{mol})$, Chicoric acid with Envelope protein $(-58.26 \mathrm{kcal} / \mathrm{mol})$, reserpine with ZIKA virus NS2B-NS3 protease $(61.45 \mathrm{kcal} / \mathrm{mol})$ and finally, rosmarinic acid shows best binding affinity with NS5-RdRP (-51.26 kcal/mol) (Figure 2, Table 2). The scores of top candidates were either higher or close some instances than pinocembrin, a positive control used in the present study (Table 2).

Luteone possessed protective activity against fungal infection (Harborne et al., 1976). Reserpine used as an antivral against SARS-CoV virus in europe and USA and also shows Antihypertensive, Antipsychotic properties (Jones 2004 and Baumeisteret al., 2003). Chicoric acid shows antiviral potency against HIV-1 virus (Lin et al., 1999 and Reinke et al., 2004). Rosmarinic acid is effective against Japanese encephalitis virus as antiviral and also shows Antioxidant, Anti-inflammatory phenomenon (Swarup et al., 2007 and Alagawanyet al., 2017) (Table 1).

Our current findings disclosed the molecular interactions of the top drugs Candidates with key proteins from ZIKA virus (Figure 2, Table 2). The binding modes of our top drugs were simililar with the peptide boronic acid which used as a proteasome inhibitor to determine the crystal structure of the ZIKA protease (Lei et al., 2016) Hydrophobicity is such a large contributor to protein complex stability (Van et al., 2015). The top candidates were well fitted into the active pocket of ZIKA protease protein where several hydrophobic amino acid residues including 
Met51, Ala1132, Val1155, Gly1133, Pro1131, Val1036 creates a hydrophobic atmosphere, which may help in complexes stabilization. The other protein docked complexes amino acids from 31 to 61 positions were crucial for the binding interactions of ZIKAV Capsid protein (5YGH). Where Capsid protein Arg32, Ala35, Leu33, Lys31 amino acid was involved in most cases to formed the docked complex with phyto-ligands. The ligands shows better binding affinity for 143-145, 301-303 and 361-374 regions for envelop protein (5JHM) and most dominant amino acids for interactions with the ligands were Leu300,Lys301, Val303, Val364, Ala361, Asn362, Thr366, Val143, Gly 145. The protein amino acid 403-423 regions were identified as top surface hotspots for NS5-RdRP (5U04) protein and among binding residues Ala423, Ala408, Lys403 were found most of the cases. In molecular dynamic study, Proteinligand complex deformability analysis showes that the distortions were lower atomic distortion and higher Eigen values as well which strengthen our statement i.e. complexes shows resistance to deform and remain stable (Figure 4C,5C,6C,7C). The B factor analysis finds a loop region into Envelope-Chicoric acid complex (Figure 4B).The RMSF plot shows minor fluctuations, reflecting the uninterrupted interaction between the protein-ligand complex (Figure 5E,6E,7E). But Envelope-Chicoric acid complex shows a higher bump may be because of a loop region (Figure 4E). In RMSD plot, fluctuations for all complexes were remain within $2 \AA$ (Figure 5D,6D,7D) but Envelope-Chicoric acid fluctuation ranging to $6 \AA$ confirming a bit flexibility (Figure 4D).

ADME results, whether experimentally evaluated or estimated, gives crucial information into how the body actually treats or recognizes a substance. Therefore, although a drug lead can demonstrate phenomenal in vitro effectiveness, weak ADME outcomes almost inevitably terminate its development (Wishart 2007). In predicting potential ADME and toxicity concerns and reducing the number of tests requiring animal experimentation where computational approaches play a key role. To investigate their drug profiles, the top drug applicants were then hired for ADME review. However, none of the metabolites displayed any adverse effects that could decrease their properties of drug likeness. ZIKA often do not attack the brain tissue (Centers for Disease Control and Prevention). Thus, there is no need to permeate the blood brain barrier (BBB) for being an effective molecule against ZIKA. However, no BBB permeates were found among the top drug candidates (Table 3). The ADME analysis shows our top predicted bio active drug candidate has drug likeliness properties (Figure8, Table 3). The toxicity pattern also 
shows there are no undesirable consequences possessed by these compounds (Table 4). Maximum predicted of the target class for the top drug candidates belonged to the categories of enzymes (e.g. protease,hydrolase, Phosphatase) (Figure 9, Table 5). The similarity analysis displays several similar approved and experimental drug compounds (e.g. Isoformononetin, Deserpidine, Rescinnamine) which may have the potency to cease ZIKA infection (Table 6). The inquiry could be helpful in unraveling the primary drug target hotspot and the medicinal chemistry of the investigational drugs currently being studied against ZIKA.

\section{Conclusion}

The findings indicate that our top predicted bio-active natural drug candidates may be potential inhibitor against ZIKA Virus. Our research findings are promising and for experimental validation we highly recommend further in-vivo trial. This study may also open a door to design a new candidate with better inhibitory activity against notorious ZIKA virus in near future.

\section{Conflict of interest}

The authors declare that they have no conflict of interests.

\section{Funding information}

This research did not receive any specific grant from funding agencies in the public, commercial or not-for-profit sectors.

\section{Acknowledgements}

Authors would like to acknowledge the Department of Plant and Environmental Biotechnology of Sylhet Agricultural University, Sylhet-3100, Bangladesh for the technical support of this research. 


\section{References}

Aggarwal M, Leser GP, Lamb RA. Repurposing Papaverine as an Antiviral Agent against Influenza Viruses and Paramyxoviruses. Journal of Virology.2020;94(6):e01888-19. https://doi.org/10.1128/JVI.01888-19.

Ahmed, S.R., Romi, I.J., Ahmed, J., Hasan, M., Roy, R. and Khan, M.M.H., J Adv Biotechnol Exp Ther. 2019. Phytochemical profiling and antioxidant potentiality of medicinal plants along with their antibacterial efficacy, 2(3): 140-145.

Alagawany M, Abd El-Hack ME, Farag MR, Gopi M, Karthik K, Malik YS, Dhama K. Rosmarinic acid: modes of action, medicinal values and health benefits. Anim Health Res Rev. 2017;18(2):167-176. https://doi.org/10.1017/S1466252317000081.

Alché LE, Ferek GA, Meo M, Coto CE, Maier MS.An antiviral meliacarpin from leaves of Meliaazedarach L. Journal of Biosciences. 2003; 58(3-4):215219.https://doi.org/10.1515/znc-2003-3-413.

Atun, S., Handayani, S. and Frindryani, L.F., 2017, August. Identification and antioxidant activity test of bioactive compound produced from ethanol extract of temukunci (Boesenbergia rotunda). In AIP Conference Proceedings (Vol. 1868, No. 1, p. 020007).AIP Publishing LLC.

Azim, K.F., Ahmed, S.R., Banik, A., Khan, M.M.R., Deb, A. and Somana, S.R., 2020. Screening and druggability analysis of some plant metabolites against SARS-CoV-2: An integrative computational approach. Informatics in Medicine Unlocked, p.100367.

Balani, S.K., Miwa, G.T., Gan, L.S., Wu, J.T. and Lee, F.W., 2005. Strategy of utilizing in vitro and in vivo ADME tools for lead optimization and drug candidate selection. Current topics in medicinal chemistry, 5(11), pp.1033-1038

Banik, A., Ahmed, S.R., Sajib, E.H., Deb, A., Sinha, S. and Azim, K.F., 2020. Identification of potential inhibitory analogs of metastasis tumor antigens (MTAs) using bioactive compounds: revealing therapeutic option to prevent malignancy. bioRxiv. 
Banik, A., Mondal, M.F., Khan, M.M.R., Ahmed, S.R. and Hasan, M.M., 2020. Screening and potent applicability analysis of commonly used pesticides against desert locust: an integrative entomo-informatics approach. bioRxiv.

Banik, Anik; Sajib, Emran; Deb, Anamika; Ahmed, Sheikh Rashel; Islam, Md- Tariqul; Roy, Soykot; et al. (2020): Identification of Potential Phytochemical Inhibitors as Promising Therapeutics Against SARS-CoV-2 and Molecular Dynamics Simulation. ChemRxiv. Preprint. https://doi.org/10.26434/chemrxiv.13182965.v1

Baumeister AA, Hawkins MF, Uzelac SM. The myth of reserpine-induced depression: role in the historical development of the monoamine hypothesis. J HistNeurosci. 2003;12(2):207-20. https://doi.org/10.1076/jhin.12.2.207.15535.

Bene J, Hadzsiev K. \&Melegh B. Role of carnitine and its derivatives in the development and management of type 2 diabetes. Nutr\& Diabetes.20188(1):8). https://doi.org/10.1038/s41387018-0017-1.

Buechler, C.R., Bailey, A.L., Weiler, A.M., Barry, G.L., Breitbach, M.E., Stewart, L.M., Jasinska, A.J., Freimer, N.B., Apetrei, C., Phillips-Conroy, J.E. and Jolly, C.J., 2017. Seroprevalence of Zika virus in wild African green monkeys and baboons. Msphere, 2(2).

Bulduk, I. and Karafakıoğlu, Y.S., Evaluation of Galantamine, Phenolics, Flavonoids and Antioxidant Content of Galanthus Species in Turkey. International Journal of Biochemistry Research \& Review. 25(1): 1-12, 2019

Bullard-Feibelman, K.M., Govero, J., Zhu, Z., Salazar, V., Veselinovic, M., Diamond, M.S. and Geiss, B.J., 2017. The FDA-approved drug sofosbuvir inhibits Zika virus infection. Antiviral research, 137, pp.134-140.

Can Baser, K.H., 2008.Biological and pharmacological activities of carvacrol and carvacrol bearing essential oils. Current pharmaceutical design, 14(29), pp.31063119.https://doi.org/10.2174/138161208786404227 
Canning, C., Sun, S., Ji, X., Gupta, S. and Zhou, K., 2013. Antibacterial and cytotoxic activity of isoprenylatedcoumarinmammea A/AA isolated from Mammeaafricana. Journal of ethnopharmacology, 147(1), pp.259-262.https://doi.org/10.1016/j.jep.2013.02.026

Cappelletti S, Daria P, Sani G, Aromatario M. Caffeine: Cognitive and Physical Performance Enhancer or Psychoactive Drug?CurrNeuropharmacol. 2015; 13(1): 71-88.doi: $10.2174 / 1570159 X 13666141210215655$.

Chen Q, Chao R, Chen H, Hou X, Yan H, Zhou S, Peng W, Xu A. Antitumor and neurotoxic effects of novel harmine derivatives and structure-activity relationship analysis. Cancer Cell Biology. International Journal of cancer. 2005;114:5. https://doi.org/10.1002/ijc.20703.

Chen, L., Zhao, L., Zhang, C. and Lan, Z., 2014. Protective effect of p-cymene on lipopolysaccharide-induced acute lung injury in mice.Inflammation, 37(2), pp.358364.https://doi.org/10.1007/s10753-013-9747-3

Cheuka, P.M., Mayoka, G., Mutai, P. and Chibale, K., 2017. The role of natural products in drug discovery and development against neglected tropical diseases. Molecules, 22(1), p.58.

da Cunha, A.J.L.A., de Magalhães-Barbosa, M.C., Lima-Setta, F., de Andrade Medronho, R. and Prata-Barbosa, A., 2017. Microcephaly case fatality rate associated with Zika virus infection in Brazil: current estimates. The Pediatric infectious disease journal, 36(5), pp.528-530.

Dai, L., Song, J., Lu, X., Deng, Y.Q., Musyoki, A.M., Cheng, H., Zhang, Y., Yuan, Y., Song, H., Haywood, J. and Xiao, H., 2016. Structures of the ZIKA virus envelope protein and its complex with a flavivirus broadly protective antibody. Cell host \& microbe, 19(5), pp.696704.

Daina, A., Michielin, O. and Zoete, V., 2017. SwissADME: a free web tool to evaluate pharmacokinetics, drug-likeness and medicinal chemistry friendliness of small molecules. Scientific reports, 7, p.42717.

Daina, A., Michielin, O. and Zoete, V., 2019. SwissTargetPrediction: updated data and new features for efficient prediction of protein targets of small molecules. Nucleic acids research, 47(W1), pp.W357-W364. 
DeLano, W.L., 2002. Pymol: An open-source molecular graphics tool. CCP4 Newsletter on protein crystallography, 40(1), pp.82-92.

Dick, G.W.A., Kitchen, S.F. and Haddow, A.J., 1952. Zika virus (I). Isolations and serological specificity. Transactions of the royal society of tropical medicine and hygiene, 46(5), pp.509520.

Ghildiyal R., Prakash V., Chaudhary V.K., Gupta V., Gabrani R. (2020) Phytochemicals as Antiviral Agents: Recent Updates. In: Swamy M. (eds) Plant-derived Bioactives. Springer, Singapore.https://doi.org/10.1007/978-981-15-1761-7_12

Godoy, A.S., Lima, G.M., Oliveira, K.I., Torres, N.U., Maluf, F.V., Guido, R.V. and Oliva, G., 2017. Crystal structure of ZIKA virus NS5 RNA-dependent RNA polymerase. Nature communications, 8(1), pp.1-6.

Grienke, U., Richter, M., Braun, H., Kirchmair, J., von Grafenstein, S., Liedl, K.R., Schmidtke, M. and Rollinger, J.M., 2013. New insights into the anti-influenza activity of licorice constituents.PlantaMedica, 79(13), p.PG3.DOI: 10.1055/s-0033-1352073

Habbu, P.V., Mahadevan, K.M., Shastry, R.A. and Manjunatha, H., 2009. Antimicrobial activity of flavanoid sulphates and other fractions of Argyreia speciosa (Burm. f) Boj.

Han H, Davis ME.Single-antibody, targeted nanoparticle delivery of camptothecin. Molecular pharmaceutics.2013;10:2558-2567.doi: 10.1021/mp300702x.

Harborne, J.B., Ingham, J.L., King, L. and Payne, M., 1976. The isopentenyl isoflavone luteone as a pre-infectional antifungal agent in the genus Lupinus. Phytochemistry, 15(10), pp.1485-1487.

Harborne, J.B., Ingham, J.L., King, L. and Payne, M., 1976.The isopentenylisoflavoneluteone as a pre-infectional antifungal agent in the genus Lupinus.Phytochemistry, 15(10), pp.14851487.https://doi.org/10.1016/S0031-9422(00)88921-9

Herrmann R, Roller J, Polednik C, Schmidt M. Effect of chelidonine on growth, invasion, angiogenesis and gene expression in head and neck cancer cell lines. OncolLett. 2018;16(3): 3108-3116.doi: 10.3892/ol.2018.903. 
Hirono, S., 2002. An introduction to the computer-aided structure-based drug design--applications of bioinformatics to drug discovery. Rinsho byori. The Japanese journal of clinical pathology, 50(1), pp.45-51.

Ivanov, A.S., Veselovsky, A.V., Dubanov, A.V. and Skvortsov, V.S., 2006. Bioinformatics platform development: from gene to lead compound. Methods in molecular biology (Clifton, NJ), 316, pp.389-431.

J. Hewlings S, S. Kalman D.Curcumin: A Review of Its' Effects on Human Health. Foods. 2017; 6(10): 92. https://doi.org /10.3390/foods6100092.

Jones, S., 2004. Targeting SARS. Nature Reviews Microbiology, 2(9), pp.686-686.

Joseph, J., Bhaskaran, R., Kaliraj, M., Muthuswamy, M. and Suresh, A., 2017. Molecular Docking of Phytoligands to the viral protein receptor P. monodon Rab7. Bioinformation, 13(4), p.116.

Karimi, A., Majlesi, M. and Rafieian-Kopaei, M., 2015. Herbal versus synthetic drugs; beliefs and facts. Journal of nephropharmacology, 4(1), p.27.

Kim, J.K. and Park, S.U., 2017. Pharmacological aspects of galantamine for the treatment of Alzheimer's disease. EXCLI journal, 16, p.35-39.http://dx.doi.org/10.17179/excli2016-820

Kim, S., Thiessen, P.A., Bolton, E.E., Chen, J., Fu, G., Gindulyte, A., Han, L., He, J., He, S., Shoemaker, B.A. and Wang, J., 2016. PubChem substance and compound databases. Nucleic acids research, 44(D1), pp.D1202-D1213.

Kinoshita, T., Saitoh, T. and Shibata, S., 1976.The occurrence of an isoflavene and the corresponding isoflavone in licorice root.Chemical and Pharmaceutical Bulletin, 24(5), pp.991-994.

Kitchen, D.B., Decornez, H., Furr, J.R. and Bajorath, J., 2004. Docking and scoring in virtual screening for drug discovery: methods and applications. Nature reviews Drug discovery, 3(11), pp.935-949. 
Koc, S., Isgor, B.S., Isgor, Y.G., Shomali Moghaddam, N. and Yildirim, O., 2015. The potential medicinal value of plants from Asteraceae family with antioxidant defense enzymes as biological targets. Pharmaceutical biology, 53(5), pp.746-751.

Krauer, F., Riesen, M., Reveiz, L., Oladapo, O.T., Martínez-Vega, R., Porgo, T.V., Haefliger, A., Broutet, N.J., Low, N. and WHO Zika Causality Working Group, 2017. Zika virus infection as a cause of congenital brain abnormalities and Guillain-Barré syndrome: systematic review. PLoS medicine, 14(1), p.e1002203.

Krishna S, Bustamante L, K. Haynes R and M. Staine H.Artemisinins: their growing importance in medicine. Trends Pharmacol Sci. 2008; 29(10): 520-527. doi: 10.1016/j.tips.2008.07.004.

Kuete V, Tangmouo JG, Meyer JJ, Lall N. Diospyrone, crassiflorone and plumbagin: three antimycobacterial and antigonorrhoealnaphthoquinones from two Diospyros spp. International Journal of Antimicrobial Agents.2009;34(4):322-325.https://doi.org /10.1016/j.ijantimicag.2009.04.008.

Kumar MAS, Nair M, Hema PS, Mohan J, Santhoshkumar TR. Pinocembrin triggers Bax-dependent mitochondrial apoptosis in colon cancer cells. Molecular Carcinogenesis. 2007;46(3):23124.doi: $10.1002 / \mathrm{mc} .20272$.

Le Lee, J., Loe, M.W.C., Lee, R.C.H. and Chu, J.J.H., 2019. Antiviral activity of pinocembrin against Zika virus replication. Antiviral Research, 167, pp.13-24.

Lee, J. L., Loe, M., Lee, R., \& Chu, J. (2019).Antiviral activity of pinocembrin against ZIKA virus replication.Antiviral research, 167, 13-24. https://doi.org/10.1016/j.antiviral.2019.04.003

Li, S.Y., Chen, C., Zhang, H.Q., Guo, H.Y., Wang, H., Wang, L., Zhang, X., Hua, S.N., Yu, J., Xiao, P.G. and Li, R.S., 2005.Identification of natural compounds with antiviral activities against SARS-associated coronavirus. Antiviral research, 67(1), pp.18-23. https://doi.org/10.1016/j.antiviral.2005.02.007

Lin, Z., Neamati, N., Zhao, H., Kiryu, Y., Turpin, J.A., Aberham, C., Strebel, K., Kohn, K., Witvrouw, M., Pannecouque, C. and Debyser, Z., 1999. Chicoric acid analogues as HIV-1 integrase inhibitors. Journal of medicinal chemistry, 42(8), pp.1401-1414. 
Liu F, Liu YC, Jiang WW, He J, Wu XD, Peng LY, Su J, Cheng X, Zhao QS. Carinatines A and B, Lycopodium Alkaloids from Phlegmariuruscarinatus.Nat Prod Bioprospect. 2014 Aug;4(4):221-5. doi: 10.1007/s13659-014-0030-6. Epub 2014

López-Blanco, J. R. , Aliaga, J. I. , Quintana-Ortí, E. S. , \& Chacón, P. (2014). iMODS: Internal coordinates normal mode analysis server. Nucleic Acids Research , 42 (Web Server issue), W271-W276. https://doi.org/10.1093/nar/gku339

López-Meyer, M., Nessler, C. L., \& McKnight, T. D. (1994).Sites of accumulation of the antitumor alkaloid camptothecin in Camptothecaacuminata.Plantamedica, 60(06), 558-560.

Losso, J.N., Bansode, R.R., Trappey II, A., Bawadi, H.A. and Truax, R., 2004. In vitro antiproliferative activities of ellagic acid.The Journal of nutritional biochemistry, 15(11), pp.672678.https://doi.org/10.1016/j.jnutbio.2004.06.004

Macnamara, F.N., 1954. Zika virus: a report on three cases of human infection during an epidemic of jaundice in Nigeria. Transactions of the royal society of tropical medicine and hygiene, 48(2), pp.139-145.

Maheshwari, R.K., Singh, A.K., Gaddipati, J. and Srimal, R.C., 2006. Multiple biological activities of curcumin: a short review. Life sciences, 78(18), pp.20812087.https://doi.org/10.1016/j.1fs.2005.12.007

Marchese A, Arciola CR, Coppo E, Barbieri R, Barreca D, Chebaibi S, Sobarzo-Sánchez E, Nabavi SF, Nabavi SM, Maria Daglia. The natural plant compound carvacrol as an antimicrobial and anti-biofilm agent: mechanisms, synergies and bio-inspired anti-infective materials. 2018;34(6):630-656. https://doi.org/10.1080/08927014.2018.1480756.

Marchese, A., Orhan, I.E., Daglia, M., Barbieri, R., Di Lorenzo, A., Nabavi, S.F., Gortzi, O., Izadi, M. and Nabavi, S.M., 2016. Antibacterial and antifungal activities of thymol: A brief review of the literature. Food chemistry, 210: 402-414. https://doi.org/10.1016/j.foodchem.2016.04.111 
Marchette, N.J., Garcia, R. and Rudnick, A., 1969. Isolation of Zika virus from Aedes aegypti mosquitoes in Malaysia. The American journal of tropical medicine and hygiene, 18(3), pp.411-415.

Mashiach E, Schneidman-Duhovny D, Andrusier N, Nussinov R, Wolfson HJ. FireDock: a web server for fast interaction refinement in molecular docking. Nucleic Acids Res 2008;36(suppl_2):W229-32.

Meng, X.Y., Zhang, H.X., Mezei, M. and Cui, M., 2011. Molecular docking: a powerful approach for structure-based drug discovery. Current computer-aided drug design, 7(2), pp.146-157.

Morales P, Reggio PH, Jagerovic N. 2017.An Overview on Medicinal Chemistry of Synthetic and Natural Derivatives of Cannabidiol. Front Pharmacol. 2017;8:422. doi:10.3389/fphar.2017.00422

Morris, G.M. and Lim-Wilby, M., 2008. Molecular docking. In Molecular modeling of proteins (pp. 365-382). Humana Press.

Mounce, B.C., Cesaro, T., Carrau, L., Vallet, T. and Vignuzzi, M., 2017. Curcumin inhibits Zika and chikungunya virus infection by inhibiting cell binding. Antiviral research, 142, pp.148-157.

Ngouela S, Ndjakou BL, Tchamo DN, Zelefack F, Tsamo E, Connolly JD. A prenylatedxanthone with antimicrobial activity from the seeds of Symphoniaglobulifera. Nat Prod Res. 2005; 19(1):23-7.https://doi.org /10.1080/14786410310001643876.

Ngouela, S., Lenta, B.N., Noungoue, D.T., Ngoupayo, J., Boyom, F.F., Tsamo, E., Gut, J., Rosenthal, P.J. and Connolly, J.D., 2006. Anti-plasmodial and antioxidant activities of constituents of the seed shells of Symphoniaglobulifera Linn f. Phytochemistry, 67(3), pp.302-306.https://doi.org/10.1016/j.phytochem.2005.11.004

O'Boyle, N.M., Banck, M., James, C.A., Morley, C., Vandermeersch, T. and Hutchison, G.R., 2011. Open Babel: An open chemical toolbox. Journal of cheminformatics, 3(1), p.33.

Ooi, L.S., Li, Y., Kam, S.L., Wang, H., Wong, E.Y. and Ooi, V.E., 2006. Antimicrobial activities of cinnamon oil and cinnamaldehyde from the Chinese medicinal herb Cinnamomum cassia Blume. The American journal of Chinese medicine, 34(03), pp.511-522. 
Panwar U, Singh SK.An Overview on ZIKA Virus and the Importance of Computational Drug Discovery. J Explor Res Pharmacol 2018;3(2):43-51. doi: 10.14218/JERP.2017.00025.

Pereyra, C.E., Dantas, R.F., Ferreira, S.B. et al. The diverse mechanisms and anticancer potential of naphthoquinones. Cancer Cell Int 19, 2019; 207. https://doi.org/10.1186/s12935-019-0925-8.

Pires, D.E., Blundell, T.L. and Ascher, D.B., 2015. pkCSM: predicting small-molecule pharmacokinetic and toxicity properties using graph-based signatures. Journal of medicinal chemistry, 58(9), pp.4066-4072.

Prasad S and K. Tyag A. "Ginger and Its Constituents: Role in Prevention and Treatment of Gastrointestinal Cancer", Gastroenterology Research and Practice.2015;2015:11. https://doi.org/10.1155/2015/142979.

Priyadarsini K.I. The chemistry of curcumin: From extraction to therapeutic agent. Molecules. 2014;19(12): 20091-20112; https://doi.org/10.3390/molecules191220091.

Priyadarsini KI, Khopde SM, Kumar SS, Mohan H. Free radical studies of ellagic acid, a natural phenolic antioxidant. J Agric Food Chem. 2002;50(7):2200-6.: https://doi.org /10.1021/jf011275g.

Rahman, M.R., Banik, A., Chowdhury, I.M., Sajib, E. and Sarkar, S., 2020. Virtual Screening of Some Antivirals That Can Be Repurposed As Potential Effective Drugs against SARS-CoV2.

Rana, I.S., Rana, A.S. and Rajak, R.C., 2011. Evaluation of antifungal activity in essential oil of the Syzygiumaromaticum (L.) by extraction, purification and analysis of its main component eugenol.Brazilian Journal of Microbiology, 42(4), pp.1269-1277. https://doi.org/10.1590/S1517-83822011000400004

Reinke RA, Lee DJ, McDougall BR, King PJ, Victoria J, Mao Y, Lei X, Reinecke MG, Robinson WE Jr. L-chicoric acid inhibits human immunodeficiency virus type 1 integration in vivo and is a noncompetitive but reversible inhibitor of HIV-1 integrase in vitro. Virology. 2004 Sep 1;326(2):203-19. doi: 10.1016/j.virol.2004.06.005. PMID: 15302207. 
Roe, D. R. , \& Cheatham, T. E. (2013). III. PTRAJ and CPPTRAJ: Software for processing and analysis of molecular dynamics trajectory data. Journal of Chemical Theory and Computation , 9 (7), 3084-3095. https://doi.org/10.1021/ct400341p.

Roman Junior, W.A., Gomes, D.B., Zanchet, B., Schönell, A.P., Diel, K.A., Banzato, T.P., Ruiz, A.L., Carvalho, J.E., Neppel, A., Barison, A. and Santos, C.A.M., 2017. Antiproliferative effects of pinostrobin and 5, 6-dehydrokavain isolated from leaves of Alpiniazerumbet.RevistaBrasileira de Farmacognosia, 27(5), pp.592-598. https://doi.org/10.1016/j.bjp.2017.05.007

Rose, P.W., Prlić, A., Altunkaya, A., Bi, C., Bradley, A.R., Christie, C.H., Costanzo, L.D., Duarte, J.M., Dutta, S., Feng, Z. and Green, R.K., 2016. The RCSB protein data bank: integrative view of protein, gene and 3D structural information. Nucleic acids research, p.gkw1000.

Roy M, Liang L, Xiao X, Feng P, Ye M, Liu J. Lycorine: a prospective natural lead for anticancer drug discovery. Biomed Pharmacother. 2018;107:615-624. https://doi.org/10.1016/j.biopha.2018.07.147.

Saad EM, Madbouly A, Ayoub N, El Nashar RM. Preparation and application of molecularly imprinted polymer for isolation of chicoric acid from Chicoriumintybus L. medicinal plant. Anal ChimActa.2015; 877: 80-9.DOI: 10.1016/j.aca.2015.03.047.

Saiz J-C, Martín-Acebes MA. 2017. The race to find antivirals for ZIKA virus. Antimicrob Agents Chemother 61(6):e00411-17. https://doi.org/10.1128/AAC.00411-17.

Salehi B, Mishra AP, Nigam M, Sener B, Kilic M, Sharifi-Rad M, Fokou PVT, Martins N, SharifiRad J. Resveratrol: A Double-Edged Sword in Health Benefits. Biomedicines. 2018;6(3):91. doi: 10.3390/biomedicines6030091.

Santin, J.R., Lemos, M., Klein-Júnior, L.C., Machado, I.D., Costa, P., de Oliveira, A.P., Tilia, C., de Souza, J.P., de Sousa, J.P.B., Bastos, J.K. and de Andrade, S.F., 2011.Gastroprotective activity of essential oil of the Syzygiumaromaticum and its major component eugenol in different animal models.Naunyn-Schmiedeberg's archives of pharmacology, 383(2), pp.149158.https://doi.org/10.1007/s00210-010-0582-x 
Schneidman-Duhovny, D., Inbar, Y., Nussinov, R. and Wolfson, H.J., 2005. PatchDock and SymmDock: servers for rigid and symmetric docking. Nucleic acids research, 33(suppl_2), pp.W363-W367.

Shang, Z., Song, H., Shi, Y., Qi, J. and Gao, G.F., 2018. Crystal structure of the capsid protein from ZIKA virus. Journal of molecular biology, 430(7), pp.948-962.

Shen Y-C, Wang L-T, Khalil AT, Kuo Y-H (2004) Chromanones and dihydrocoumarins from Calophyllumblancoi. Chem Pharm Bull 52(4):402-405

Siani AC, Ramos MF, Menezes-de-Lima O Jr, Ribeiro-dos-Santos R, Fernadez-Ferreira E, Soares RO, Rosas EC, Susunaga GS, Guimarães AC, Zoghbi MG, Henriques MG. Evaluation of anti-inflammatory-related activity of essential oils from the leaves and resin of species of Protium. J Ethnopharmacol. 1999 Jul;66(1):57-69. doi: 10.1016/s0378-8741(98)00148-2. PMID: 10432208.

Slusarenko AJ, Patel A, Portz D. Control of plant diseases by natural products: Allicin from garlic as a case study. Eur.J.Plant.Pathol. 2008;121:313-322.doi: 10.1007/978-1-4020-8780-6-10.

Swarup, V., Ghosh, J., Ghosh, S., Saxena, A. and Basu, A., 2007. Antiviral and anti-inflammatory effects of rosmarinic acid in an experimental murine model of Japanese encephalitis. Antimicrobial agents and chemotherapy, 51(9), pp.3367-3370.

Talontsi FM, Lamshöft M, Bauer JO., Razakarivony AA., Andriamihaja B, Strohmann C, Spiteller M. Antibacterial and antiplasmodial constituents of Beilschmiediacryptocaryoides. J. Nat. Prod. 2013;76:97-102. doi: 10.1021/np300773x.

Thakur AK, Rai G, Chatterjee SS, Kumar V. Beneficial effects of an Andrographispaniculata extract and andrographolide on cognitive functions in streptozotocin- induced diabetic rats.Pharm Biol.2016;54(9):1528-38doi: 10.3109/13880209.2015.1107107.

Van Dijk, E., Hoogeveen, A. and Abeln, S., 2015. The hydrophobic temperature dependence of amino acids directly calculated from protein structures. PLoS Comput Biol, 11(5), p.e1004277. 
Vázquez-Calvo, Á., Jiménez de Oya, N., Martín-Acebes, M.A., Garcia-Moruno, E. and Saiz, J.C., 2017. Antiviral properties of the natural polyphenols delphinidin and epigallocatechin gallate against the flaviviruses West Nile virus, Zika virus, and dengue virus. Frontiers in microbiology, 8, p.1314.

Wang H, Li M-Y, Wu J, 2012. Chemical Constituents and Some Biological Activities of Plants from the Genus Ceriops.Chemistry and Biodiversity. 9: 1-11

Wang Q, He J, Wu D, Wang J, Yan J, Li H. Interaction of $\alpha$-cyperone with human serum albumin: determination of the binding site by using Discovery Studio and via spectroscopic methods. J Lumin 2015; 164:81-5.

Wang, Q., He, J., Wu, D., Wang, J., Yan, J. and Li, H., 2015. Interaction of $\alpha$-cyperone with human serum albumin: Determination of the binding site by using Discovery Studio and via spectroscopic methods. Journal of Luminescence, 164, pp.81-85.

Wishart, D.S., 2007. Improving early drug discovery through ADME modelling. Drugs in R \& D, 8(6), pp.349-362.

World Health Organization: WHO, 20 July 2018, Zika virus (https://www.who.int/news-room/factsheets/detail/zika-virus)

Xin G, Yu M, Hu Y, Gao S, Qi Z, Sun Y, Yu W, He J \&Ji Y. Effect of lycorine on the structure and function of hepatoma cell membrane invitro and invivo, Biotechnology \& Biotechnological Equipment2020;34(1): 104-114. https://doi.org/10.1080/13102818.2020.1719019.

Yamahara J, Mochizuki M, Rong HQ, Matsuda H, Fujimura H. The anti-ulcer effect in rats of ginger constituents.J Ethnopharmacol. 1988 Jul-Aug;23(2-3):299-304. doi: 10.1016/03788741(88)90009-8.

Yang, C.M., Cheng, H.Y., Lin, T.C., Chiang, L.C. and Lin, C.C., 2007.Hippomanin a from acetone extract of Phyllanthusurinaria inhibited HSV-2 but not HSV-1 infection in vitro. Phytotherapy Research: An International Journal Devoted to Pharmacological and Toxicological Evaluation of Natural Product Derivatives, 21(12), pp.1182-1186. https://doi.org/10.1002/ptr.2232 
Yang, J. F. , Wang, F. , Chen, Y. Z. , Hao, G. F. , \& Yang, G. F. (2019). LARMD: Integration of bioinformatic resources to profile ligand-driven protein dynamics with a case on the activation of estrogen receptor. Brief Bioinformatics . 1-13. https://doi.org/10.1093/bib/bbz141

Zoete, V., Daina, A., Bovigny, C. and Michielin, O., 2016. SwissSimilarity: a web tool for low to ultra high throughput ligand-based virtual screening.

\section{Tables:}

Table 1: Plant derived compounds' name, source and their activities

\begin{tabular}{|c|c|c|c|c|}
\hline Compounds & $\begin{array}{c}\text { Pubchem } \\
\text { CID }\end{array}$ & Source & Function & References \\
\hline $\begin{array}{c}\text { Pinocembrin } \\
\text { (Control) }\end{array}$ & 68071 & $\begin{array}{c}\text { Sparattospermaleucanthu } \\
m\end{array}$ & Anticancer & $\begin{array}{l}\text { Kumaret al., } \\
2007\end{array}$ \\
\hline Allicin & 65036 & Allium sativum & Antibacterial & $\begin{array}{l}\text { Slusarenkoet a., } \\
2008\end{array}$ \\
\hline Andrographolide & 6436016 & Andrographispaniculata & Antidiabetic & $\begin{array}{c}\text { Thakuret al., } \\
2016\end{array}$ \\
\hline Apetalic acid & 341189 & Calophyllumblancoi & $\begin{array}{l}\text { Activity against tumor and } \\
\text { carcinoma }\end{array}$ & Shen et al., 2004 \\
\hline Artemisinin & 68827 & Artemisia annua $\mathrm{L}$ & Antimalarial and anti-cancer & $\begin{array}{c}\text { Krishnaet al. } \\
2008\end{array}$ \\
\hline $\begin{array}{l}\text { Beilschmiedic } \\
\text { acid A }\end{array}$ & 42646683 & Beilschmiedia species & Antibacterial, Antiplasmodial & $\begin{array}{c}\text { Talontsiet al., } \\
2013\end{array}$ \\
\hline Caffeine & 2519 & Theobroma cacao L. & $\begin{array}{c}\text { Central Nerevouis System } \\
\text { Stimulant }\end{array}$ & $\begin{array}{c}\text { Cappelletti et al., } \\
2015\end{array}$ \\
\hline Camptothecin & 24360 & Camptotheca acuminate & Antineoplastic & $\begin{array}{c}\text { Han\& Davis, } \\
\text { 2013; López- } \\
\text { Meyer et al., } \\
1994 \\
\end{array}$ \\
\hline Cannabidiol & 644019 & Cannabis species & $\begin{array}{c}\text { Antipsychotic, Anti- } \\
\text { inflammatory, } \\
\text { neuroprotective }\end{array}$ & $\begin{array}{c}\text { Morales et al., } \\
2017\end{array}$ \\
\hline Carinatine & 441591 & Phlegmariuruscarinatus & Antidiabetic & $\begin{array}{l}\text { Beneet al., 2018; } \\
\text { Liu et al., 2014 }\end{array}$ \\
\hline Ceriopsin F & 5315791 & Ceriopsdecandra & Antitumor & Wanget al., 2012; \\
\hline Chelidonine & 197810 & Chelidoniummajus L. & Anti-cancer & $\begin{array}{l}\text { Herrmannet al., } \\
2018\end{array}$ \\
\hline Chicoric acid & 5281764 & Chicoriumintybus & Antiviral & $\begin{array}{l}\text { Saad } \text { et al., 2015, } \\
\quad \text { Reinke et al., }\end{array}$ \\
\hline
\end{tabular}




\begin{tabular}{|c|c|c|c|c|}
\hline & & & & 2004 \\
\hline Cinnamaldehyde & 637511 & Cinnamomum cassia & Antibacterial & Ooi et al., 2006 \\
\hline Curcumin & 969516 & Curcuma longa & $\begin{array}{l}\text { Anticancer, Anti- } \\
\text { inflammatory }\end{array}$ & $\begin{array}{c}\text { Priyadarsiniet al., } \\
\text { 2014, J. } \\
\text { Hewlingset al., } \\
2017 \\
\text { Maheshwari, } \\
2006 \\
\end{array}$ \\
\hline Crassiflorone & 11674902 & Diospyroscrassiflora & $\begin{array}{l}\text { Antimycobacterial,Anti- } \\
\text { gonorrhoeal }\end{array}$ & Kueteet al., 2009 \\
\hline Ellagic Acid & 5281855 & Quercussp & Anti-proliferative & $\begin{array}{c}\text { Priyadarsiniet al., } \\
2002 \\
\text { Losso et al., } \\
2004 \\
\end{array}$ \\
\hline Eugenol & 3314 & Syzygiumaromaticum & $\begin{array}{c}\text { Antifungal and anti-ulcer } \\
\text { activity }\end{array}$ & $\begin{array}{c}\text { Rana et al., 2011; } \\
\text { Santin et al., } \\
2011 \\
\end{array}$ \\
\hline Luteone & 5281797 & $\begin{array}{c}\text { Lupinusalbus and lupin } \\
\text { species }\end{array}$ & Anti-fungal Properties & $\begin{array}{c}\text { Harborne et al., } \\
1976\end{array}$ \\
\hline Galantamine & 9651 & Galanthusworonowii & $\begin{array}{l}\text { Activity against Alzheimer's } \\
\text { disease }\end{array}$ & $\begin{array}{l}\text { Kim and Park, } \\
\text { 2017; Buldukand } \\
\text { Karafak1oğlu, } \\
2019\end{array}$ \\
\hline Globuliferin & 101390391 & $\begin{array}{c}\text { Symphoniaglobulifera } \\
\text { Linn } f\end{array}$ & $\begin{array}{l}\text { Anti-plasmodial, Anti- } \\
\text { microbial }\end{array}$ & $\begin{array}{l}\text { Ngouela et al., } \\
2005,2006\end{array}$ \\
\hline Glabrone & 5317652 & Glycyrrhizaglabra & Anti-influenza activity & $\begin{array}{l}\text { Kinoshita et al., } \\
\text { 1976; Grienke et } \\
\text { al., } 2013\end{array}$ \\
\hline Harmine & 5280953 & Peganumharmala & Antitumor & Chen et al., 2005 \\
\hline Hippomanin A & 323958 & Phyllanthusurinaria & Anti-HSV-2 & Yang et al., 2007 \\
\hline Lycorine & 72378 & $\begin{array}{c}\text { Cliviaminiata } \\
\text { Lycorisradiate and plant } \\
\text { speciesof } \\
\text { Amaryllidaceae family }\end{array}$ & $\begin{array}{c}\text { Antitumor, Anticancer } \\
\text { antiviral activities against } \\
\text { SARS-associated coronavirus }\end{array}$ & $\begin{array}{l}\text { Xin et al., } 2020 \text {, } \\
\text { Li et al., 2005; } \\
\text { Roy et al., } 2018\end{array}$ \\
\hline Mammea A & 53321420 & Mammea Africana & $\begin{array}{l}\text { Antibacterial and } \\
\text { antiproliferative }\end{array}$ & $\begin{array}{l}\text { Canning et al., } \\
2013\end{array}$ \\
\hline Meliacarpin & 183572 & Meliaazedarach & Antiviral & Alchéet al., 2003 \\
\hline $\begin{array}{c}\text { Naphthoquinone } \\
\text { s }\end{array}$ & 8530 & $\begin{array}{l}\text { Plant species of } \\
\text { Bignoniaceae, } \\
\text { Verbenaceae and } \\
\text { Proteaceae family }\end{array}$ & Anticancer & $\begin{array}{l}\text { Pereyraet al., } \\
2019\end{array}$ \\
\hline Papaverine & 4680 & Papaversomniferum L. & Antiviral & $\begin{array}{c}\text { Aggarwaet al., } \\
2020\end{array}$ \\
\hline Pinostrobin & 73201 & $\begin{array}{c}\text { Boesenbergia rotunda, } \\
\text { Alpiniazerumbet }\end{array}$ & $\begin{array}{c}\text { Antiproliferative and } \\
\text { antioxidant }\end{array}$ & $\begin{array}{l}\text { Roman Junior et } \\
\text { al., 2017;Atun et }\end{array}$ \\
\hline
\end{tabular}




\begin{tabular}{|c|c|c|c|c|}
\hline & & & & al.,2017 \\
\hline Reserpine & 5770 & Rauwolfia serpentine & $\begin{array}{l}\text { Antihypertensive, } \\
\text { Antipsychotic }\end{array}$ & $\begin{array}{c}\text { Baumeisteret al., } \\
2003\end{array}$ \\
\hline Resveratrol & 445154 & grapes' skin and seeds & $\begin{array}{c}\text { Antioxidant, antitumor } \\
\text { activity }\end{array}$ & Salehiet al., 2018 \\
\hline Rosmarinic acid & 5281792 & $\begin{array}{c}\text { Rosmarinusofficinalis, Lam } \\
\text { iaceae herbs }\end{array}$ & $\begin{array}{l}\text { Antioxidant, Anti- } \\
\text { inflammatory }\end{array}$ & $\begin{array}{c}\text { Alagawanyet al., } \\
2017\end{array}$ \\
\hline Thymol & 6989 & $\begin{array}{l}\text { Thymus, Ocimum, } \\
\text { Origanum genera }\end{array}$ & antibacterial and antifungal & $\begin{array}{c}\text { Marchese et al., } \\
2016 \\
\end{array}$ \\
\hline p-cymene & 7463 & Species of Protium & Anti-inflammatory & $\begin{array}{l}\text { Chen et al., 2014; } \\
\text { Siani et al., } 1999\end{array}$ \\
\hline Carvacrol & 10364 & $\begin{array}{l}\text { Origanum, Lippia, } \\
\text { Thymus, Thymbra, } \\
\text { Coridothymus,Satureja }\end{array}$ & $\begin{array}{l}\text { Antimicrobial, antitumor, } \\
\text { antiinflammatory, } \\
\text { antiparasitic, antihepatotoxic } \\
\text { activities }\end{array}$ & $\begin{array}{c}\text { Marcheseet al., } \\
2018 \\
\text { Can Baser, } 2008\end{array}$ \\
\hline Zingiberene & 92776 & Zingiberofficinale & $\begin{array}{c}\text { Chemotherapeutic agents, } \\
\text { Anti-ulcer }\end{array}$ & $\begin{array}{c}\text { Prasad et al,2015 } \\
\text { and Yamaharaet } \\
\text { al.,1988 }\end{array}$ \\
\hline
\end{tabular}

Table 2: Analysis of global binding energy and interaction sites of the top screened candidates

\begin{tabular}{|c|c|c|c|c|c|c|}
\hline Macromolecules & Ligands & $\begin{array}{l}\text { Global } \\
\text { Energy }\end{array}$ & $\mathrm{ACE}$ & Score & Area & Ligand binding residues \\
\hline \multirow[t]{5}{*}{$5 Y G H$} & $\begin{array}{l}\text { Pinocembrin } \\
\text { (Control) }\end{array}$ & -41.16 & -8.99 & 3348 & $\begin{array}{c}454.7 \\
0\end{array}$ & Gly36,Ala35,Pro35,Arg32 \\
\hline & Chicoric acid & -52.90 & -14.55 & 4544 & $\begin{array}{c}652.8 \\
0\end{array}$ & Arg32, Lys31, Pro34 \\
\hline & Luteone & -52.92 & -18.58 & 4080 & $\begin{array}{c}561.2 \\
0\end{array}$ & Arg32, Ala35, Leu33, Lys 31, Leu38, Leu39 \\
\hline & Reserpine & -37.84 & -13.29 & 5004 & $\begin{array}{c}604.8 \\
0\end{array}$ & $\begin{array}{c}\text { Arg55, Arg98, Ala58, Ile59, Ile66, Ile94, Lys60, } \\
\text { Pro61 }\end{array}$ \\
\hline & Rosmarinic acid & -48.72 & -12.90 & 3900 & $\begin{array}{c}522.1 \\
0\end{array}$ & Arg32, Ala35, Gly36, Lys 31, Pro34 \\
\hline \multirow[t]{5}{*}{$5 J H M$} & $\begin{array}{l}\text { Pinocembri } \\
\text { (Control) }\end{array}$ & -42.22 & -12.08 & 3666 & $\begin{array}{c}447.3 \\
0\end{array}$ & Leu300,Lys301,Val303,Asn362,Val364 \\
\hline & Chicoric acid & -58.26 & -14.63 & 5478 & $\begin{array}{c}652.2 \\
0\end{array}$ & $\begin{array}{c}\text { Ala361, Asn362, Gly145, Met374, Phe183, } \\
\text { Thr366, Ser304, Tyr305, Val143 }\end{array}$ \\
\hline & Luteone & -54.47 & -16.40 & 4644 & $\begin{array}{c}527.1 \\
0\end{array}$ & $\begin{array}{l}\text { Ala361, ASn362, Met374, Phe183, Leu300, } \\
\text { Val303 }\end{array}$ \\
\hline & Reserpine & -51.17 & -14.96 & 6610 & $\begin{array}{c}780.3 \\
0\end{array}$ & $\begin{array}{c}\text { Ala361, Gly145, His144, , Ile1, Lys301, Met374, } \\
\text { Met375, Phe183, Ser146, Tyr305, } \\
\text { Thr366,Val143, Val303, Val364 }\end{array}$ \\
\hline & Rosmarinic acid & -49.18 & -13.91 & 4724 & $\begin{array}{c}578.5 \\
0\end{array}$ & Leu300, Lys301, Thr366, Val143, Val364 \\
\hline \multirow[t]{3}{*}{$5 L C 0$} & $\begin{array}{l}\text { Pinocembrin } \\
\text { (Control) }\end{array}$ & -38.28 & -9.77 & 3768 & $\begin{array}{c}418.5 \\
0\end{array}$ & Gly1151, Tyr1130, Tyr1161,Val1155 \\
\hline & Chicoric acid & -50.43 & -14.23 & 5610 & $\begin{array}{c}667.1 \\
0\end{array}$ & $\begin{array}{l}\text { Ala77,Ile1123, Leu78, Lys1073,Lys1119, } \\
\text { Asp1120, Gln1074, Trp1089, Val76 }\end{array}$ \\
\hline & Luteone & -46.31 & -13.52 & 4754 & 574.3 & Ala1132, Phe84, Lys1054, Tyr1150, Tyr1161, \\
\hline
\end{tabular}




\begin{tabular}{|c|c|c|c|c|c|c|}
\hline & & & & & 0 & Val1155 \\
\hline & Reserpine & -61.45 & -18.58 & 6924 & $\begin{array}{c}828.3 \\
0\end{array}$ & $\begin{array}{c}\text { Ala1132, Asp1129, Gly1133, Tyr1130, } \\
\text { His1051,Pro1131, Tyr1161, Val1036, Val1052, } \\
\text { Val1155 }\end{array}$ \\
\hline & Rosmarinic acid & -45.28 & -13.26 & 4806 & $\begin{array}{c}537.9 \\
0\end{array}$ & Ala1132, His1051, Met51, Ser1135, Val1036 \\
\hline \multirow[t]{5}{*}{ NS5-RdRP } & $\begin{array}{l}\text { Pinocembrin } \\
\text { (Control) }\end{array}$ & -33.14 & -8.93 & 3414 & $\begin{array}{c}374.4 \\
0\end{array}$ & Arg739, Arg794, Pro744 \\
\hline & Chicoric acid & -41.25 & -10.68 & 4994 & $\begin{array}{c}581.2 \\
0\end{array}$ & $\begin{array}{c}\text { Arg731, Arg739, Arg794, Glu417, Ser798, } \\
\text { Thr796, Tyr760, Val742 }\end{array}$ \\
\hline & Luteone & -42.94 & -14.09 & 4320 & $\begin{array}{c}487.0 \\
0\end{array}$ & $\begin{array}{c}\text { Ala423, Arg483, Asn407, Glu419, Lys403, } \\
\text { Val404 }\end{array}$ \\
\hline & Reserpine & -39.68 & -12.05 & 6270 & $\begin{array}{c}779.5 \\
0\end{array}$ & $\begin{array}{l}\text { Ala408, Ala482, Asn454,Asn494, Glu495, } \\
\text { Lys403, Phe400, Trp479, Phe487, } \\
\text { Tyr453,Val452,Val606, Val404 }\end{array}$ \\
\hline & Rosmarinic acid & -51.26 & -15.35 & 4440 & $\begin{array}{c}506.7 \\
0\end{array}$ & Ala423, Ala408, Lys403, Val404 \\
\hline
\end{tabular}

Table 3: Drug profile and ADME analysis of the top four metabolites.

\begin{tabular}{|c|c|c|c|c|}
\hline Parameters & Chicoric acid & Luteone & Reserpine & $\begin{array}{c}\text { Rosmarinic } \\
\text { acid }\end{array}$ \\
\hline \multicolumn{5}{|c|}{ Physicochemical Parameters } \\
\hline Molecular weight & $474.37 \mathrm{~g} / \mathrm{mol}$ & $354.35 \mathrm{~g} / \mathrm{mol}$ & $608.68 \mathrm{~g} / \mathrm{mol}$ & $360.31 \mathrm{~g} / \mathrm{mol}$ \\
\hline Num. rotatable bonds & 11 & 3 & 10 & 7 \\
\hline No. H-bond acceptor & 12 & 6 & 10 & 8 \\
\hline No. H-bond donors & 6 & 4 & 1 & 5 \\
\hline TPSA & $208.12 \AA^{2}$ & $111.13 \AA^{2}$ & $117.78 \AA^{2}$ & $144.52 \AA^{2}$ \\
\hline \multicolumn{5}{|c|}{ Lipophilicity } \\
\hline Log Po/w (iLOGP) & 1.00 & 2.71 & 4.39 & 1.17 \\
\hline Log Po/w (WLOGP) & 1.01 & 3.79 & 3.47 & 1.65 \\
\hline Log Po/w (SILICOS-IT) & 0.88 & 3.73 & 3.94 & 1.50 \\
\hline \multicolumn{5}{|c|}{ Pharmacokinetics } \\
\hline GI absorption & Low & High & High & Low \\
\hline BBB permeant & No & No & No & No \\
\hline P-gp substrate & Yes & No & Yes & No \\
\hline CYP1A2 inhibitor & No & Yes & No & No \\
\hline CYP2C19 inhibitor & No & No & No & No \\
\hline CYP2C9 inhibitor & No & Yes & No & No \\
\hline CYP2D6 inhibitor & No & Yes & No & No \\
\hline CYP3A4 inhibitor & No & No & No & No \\
\hline \multicolumn{5}{|c|}{ Water Solubility } \\
\hline Log S (ESOL) & -3.58 & -4.97 & -5.75 & -3.44 \\
\hline Solubility & $\begin{array}{c}1.24 \mathrm{e}-01 \mathrm{mg} / \mathrm{ml} \\
2.61 \mathrm{e}-04 \mathrm{~mol} / \mathrm{l}\end{array}$ & $\begin{array}{c}3.84 \mathrm{e}-03 \mathrm{mg} / \mathrm{ml} \\
1.08 \mathrm{e}-05 \mathrm{~mol} / \mathrm{l}\end{array}$ & $\begin{array}{c}1.08 \mathrm{e}-03 \mathrm{mg} / \mathrm{ml} ; \\
1.77 \mathrm{e}-06 \mathrm{~mol} / 1\end{array}$ & $\begin{array}{c}1.31 \mathrm{e}-01 \mathrm{mg} / \mathrm{ml} \\
3.63 \mathrm{e}-04 \mathrm{~mol} / \mathrm{l}\end{array}$ \\
\hline Class & Soluble & Moderately soluble & Moderately soluble & Soluble \\
\hline
\end{tabular}




\begin{tabular}{|c|c|c|c|c|}
\hline Log S (SILICOS-IT) & -0.87 & -5.05 & -6.89 & -2.17 \\
\hline Solubility & $\begin{array}{c}6.43 \mathrm{e}+01 \mathrm{mg} / \mathrm{ml} ; \\
1.36 \mathrm{e}-01 \mathrm{~mol} / \mathrm{l}\end{array}$ & $\begin{array}{c}3.12 \mathrm{e}-03 \mathrm{mg} / \mathrm{ml} ; \\
8.81 \mathrm{e}-06 \mathrm{~mol} / \mathrm{l}\end{array}$ & $\begin{array}{c}7.81 \mathrm{e}-05 \mathrm{mg} / \mathrm{ml} ; \\
1.28 \mathrm{e}-07 \mathrm{~mol} / \mathrm{l}\end{array}$ & $\begin{array}{c}2.41 \mathrm{e}+00 \mathrm{mg} / \mathrm{ml} \\
6.70 \mathrm{e}-03 \mathrm{~mol} / \mathrm{l}\end{array}$ \\
\hline Class & Soluble & Moderately soluble & Poorly soluble & Soluble \\
\hline \multicolumn{5}{|c|}{ Medicinal Chemistry } \\
\hline Lipinski & No; 2 violations & Yes; 0 violation & No; 2 violations & Yes; 0 violation \\
\hline Leadlikeness & $\begin{array}{c}\text { No; } 2 \text { violations: } \\
\text { MW }>350 \\
\text { Rotors }>7\end{array}$ & $\begin{array}{c}\text { No; } 2 \text { violations: } \\
\text { MW>350, } \\
\text { XLOGP3>3.5 }\end{array}$ & $\begin{array}{c}\text { No; } 3 \text { violations: } \\
\text { MW }>350, \\
\text { Rotors }>7, \\
\text { XLOGP3>3.5 }\end{array}$ & $\begin{array}{l}\text { No; } 1 \text { violation: } \\
\text { MW>350 }\end{array}$ \\
\hline Bioavailability Score & 0.11 & 0.55 & 0.17 & 0.56 \\
\hline PAINS & $\begin{array}{c}1 \text { alert: } \\
\text { catechol_A }\end{array}$ & 0 alert & $\begin{array}{c}1 \text { alert: } \\
\text { indol_3yl_alk }\end{array}$ & 1 alert: catechol_A \\
\hline
\end{tabular}

Table 4: Toxicity properties analysis of top screened drug candidates

\begin{tabular}{|c|c|c|c|c|}
\hline Toxicity properties & Chicoric acid & Luteone & Reserpine & Rosmarinic acid \\
\hline Carcinogenicity & No & No & No & No \\
\hline Eye corrosion & No & No & No & No \\
\hline Eye irritation & No & Yes & No & No \\
\hline AMES toxicity & No & No & No & No \\
\hline $\begin{array}{c}\text { Max. tolerated dose } \\
\text { (human) }\end{array}$ & 0.225 & 0.581 & -0.133 & No \\
\hline $\begin{array}{c}\text { hERG I inhibitor } \\
\begin{array}{c}\text { Oral Rat Acute Toxicity } \\
\text { (LD50) }\end{array}\end{array}$ & No & No & No & 2.811 \\
\hline $\begin{array}{c}\text { Oral Rat Chronic Toxicity } \\
\text { (LOAEL) }\end{array}$ & 4.005 & 2.191 & 1.158 & 2.907 \\
\hline Hepatotoxicity & No & No & No & No \\
\hline Skin Sensitisation & No & No & No & No \\
\hline $\begin{array}{c}\text { T.Pyriformis toxicity } \\
\text { L }\end{array}$ & 0.285 & 0.319 & 0.286 & 0.302 \\
\hline
\end{tabular}

Table 5: Predicted drug targets of top screened candidates

\begin{tabular}{|c|c|c|c|c|c|}
\hline Metabolites & Drug Targets & $\begin{array}{c}\text { Common } \\
\text { Name }\end{array}$ & $\begin{array}{c}\text { Uniprot } \\
\text { ID }\end{array}$ & $\begin{array}{c}\text { Target } \\
\text { Class }\end{array}$ & Probability \\
\hline Chicoric & liver glycogen & PYGL & P06737 & Enzyme & \\
\hline
\end{tabular}




\begin{tabular}{|c|c|c|c|c|c|}
\hline \multirow[t]{3}{*}{ acid } & phosphorylase & & & & \\
\hline & Aldose reductase & AKR1B1 & P15121 & Enzyme & \\
\hline & $\begin{array}{c}\text { Matrix } \\
\text { metalloproteinase } 9\end{array}$ & MMP9 & P14780 & Protease & \\
\hline \multirow[t]{2}{*}{ Luteone } & $\begin{array}{l}\text { Protein-tyrosine } \\
\text { phosphatase 1B }\end{array}$ & PTPN1 & P18031 & Phosphatase & \\
\hline & Acetylcholinesterase & ACHE & P22303 & Hydrolase & \\
\hline \multirow[t]{3}{*}{ Reserpine } & Mu opioid receptor & OPRM1 & P35372 & $\begin{array}{c}\text { Family A G } \\
\text { protein- } \\
\text { coupled } \\
\text { receptor }\end{array}$ & \\
\hline & P-glycoprotein 1 & $\mathrm{ABCB} 1$ & P08183 & $\begin{array}{c}\text { Primary } \\
\text { active } \\
\text { transporter }\end{array}$ & \\
\hline & $\begin{array}{l}\text { Alpha-2a adrenergic } \\
\text { receptor }\end{array}$ & ADRA2A & P08913 & $\begin{array}{c}\text { Family A G } \\
\text { protein- } \\
\text { coupled } \\
\text { receptor }\end{array}$ & \\
\hline \multirow[t]{6}{*}{$\begin{array}{l}\text { Rosmarinic } \\
\text { acid }\end{array}$} & $\begin{array}{c}\text { Tyrosine-protein } \\
\text { kinase FYN }\end{array}$ & FYN & P06241 & Kinase & \\
\hline & Aldose reductase & AKR1B1 & P15121 & Enzyme & \\
\hline & Transthyretin & TTR & P02766 & $\begin{array}{l}\text { Secreted } \\
\text { protein }\end{array}$ & \\
\hline & $\begin{array}{c}\text { Matrix } \\
\text { metalloproteinase } 1\end{array}$ & MMP1 & P03956 & Protease & \\
\hline & $\begin{array}{c}\text { Matrix } \\
\text { metalloproteinase } 9\end{array}$ & MMP9 & P14780 & Protease & \\
\hline & $\begin{array}{c}\text { Matrix } \\
\text { metalloproteinase } 2\end{array}$ & MMP2 & P08253 & Protease & \\
\hline
\end{tabular}

Table 6: Predicted Structural analog molecules from Drugbank.

\begin{tabular}{|c|c|c|c|c|}
\hline Metabolites & Name & Drug Bank & Score & Status \\
\hline Chicoric acid & $\begin{array}{c}\text { 2-deoxy-3,4-bis-o-[3-(4- } \\
\text { hydroxyphenyl)propanoyl]-1-threo- } \\
\text { pentaric acid }\end{array}$ & DB08322 & 0.962 & Experimental \\
\hline Luteone & Isoformononetin & DB04202 & 0.230 & Experimental \\
\hline Reserpine & Deserpidine & DB01089 & 0.978 & Approved \\
\hline
\end{tabular}


bioRxiv preprint doi: https://doi.org/10.1101/2020 11.11.378083; this version posted November 12, 2020. The copyright holder for this preprint (which was not certified by peer review) is the author/funder, who has granted bioRxiv a license to display the preprint in perpetuity. It is made available under aCC-BY-NC-ND 4.0 International license.

\begin{tabular}{|c|c|c|c|c|}
\hline & Rescinnamine & DB01180 & 0.925 & Approved \\
\hline Rosmarinic acid & $\begin{array}{c}\text { 2-deoxy-3,4-bis-o-[3-(4- } \\
\text { hydroxyphenyl)propanoyl]-1-threo- } \\
\text { pentaric acid }\end{array}$ & DB08322 & 0.467 & Experimental \\
\hline
\end{tabular}




\section{Figures:}

A)<smiles>O=C(C=Cc1ccc(O)c(O)c1)OC(C(=O)O)C(OC(=O)C(=O)O)C(=O)O</smiles>

B)<smiles>CC(C)=CCc1c(O)cc2occ(-c3ccc(O)cc3O)c(=O)c2c1O</smiles>

D)

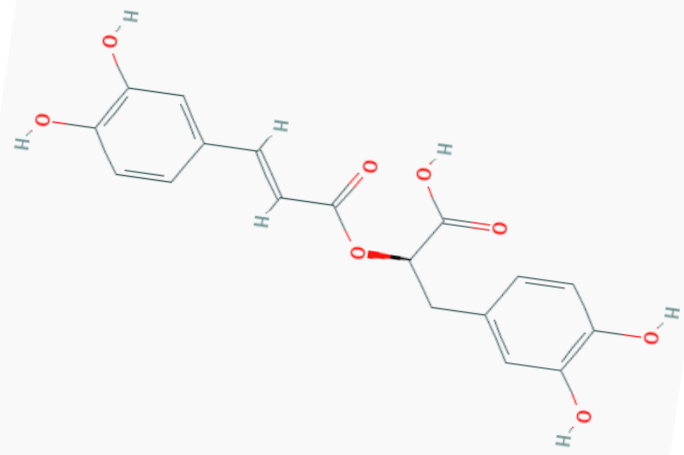

Figure 1: Chemical Structure of Chicoric acid A), Luteone B), Reserpine C), Rosmarinic acid D). 


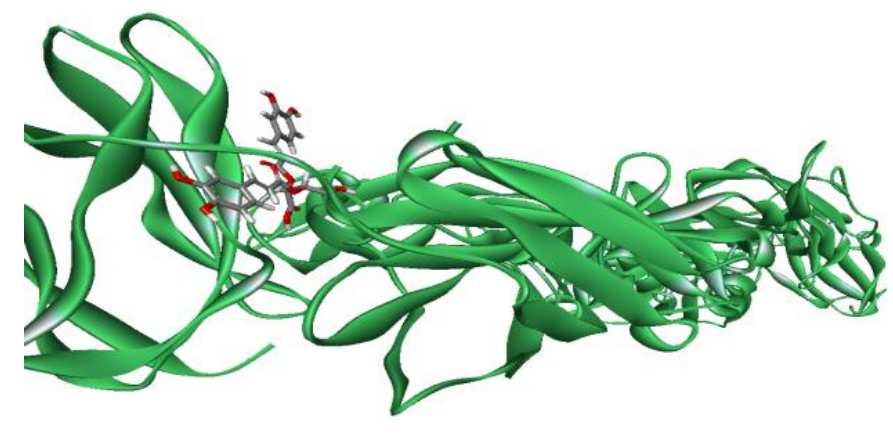

A)

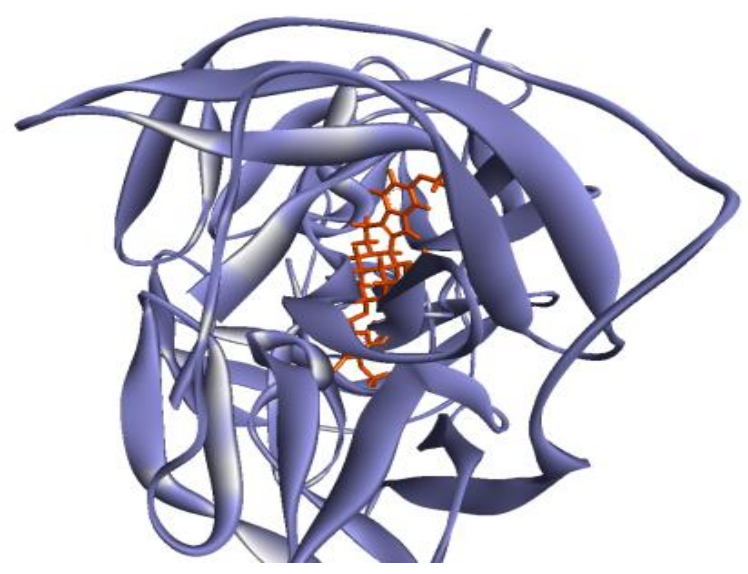

C)

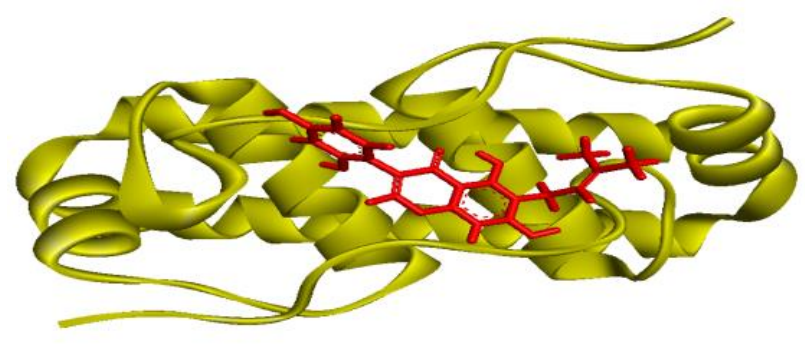

B)

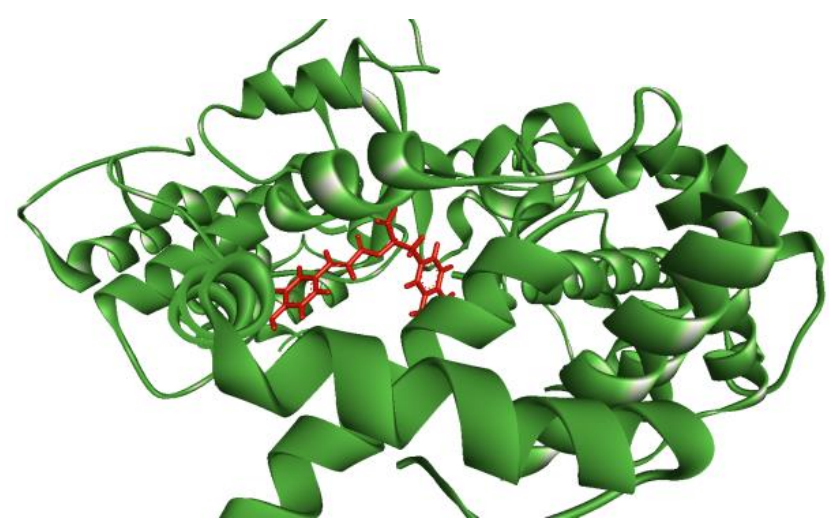

D)

Figure 2: Molecular interactions of macromolecules against ligands; Chicoric Acid A), Luteone B), Reserpine C) and Rosmarinic acid D). 


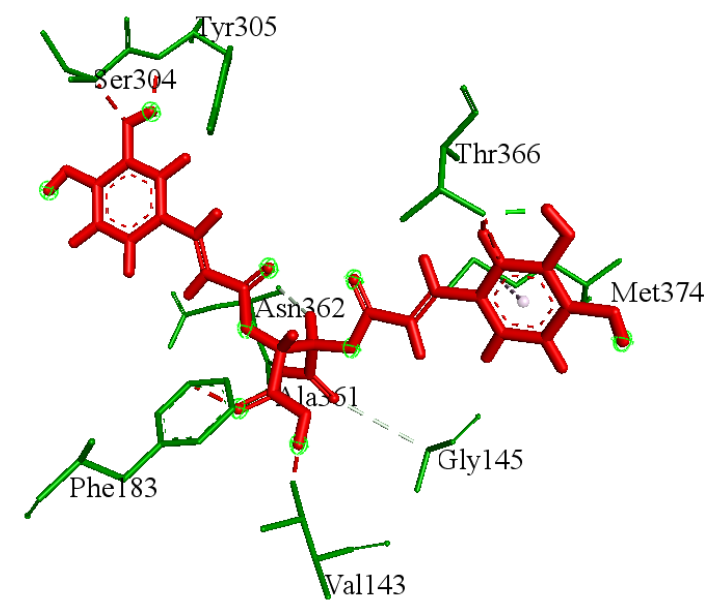

A)

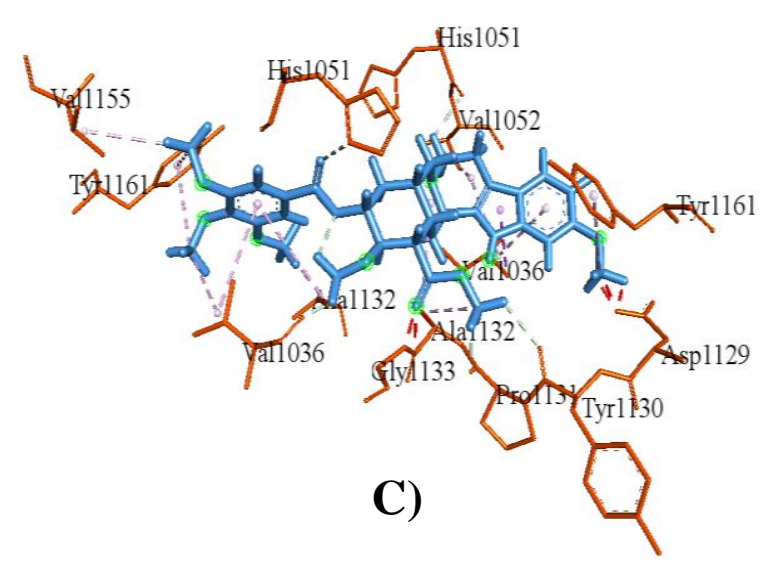

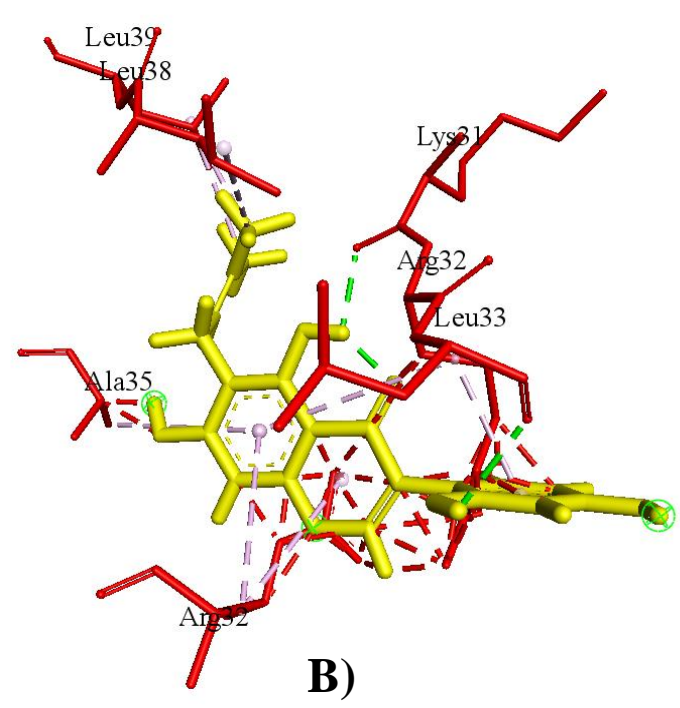

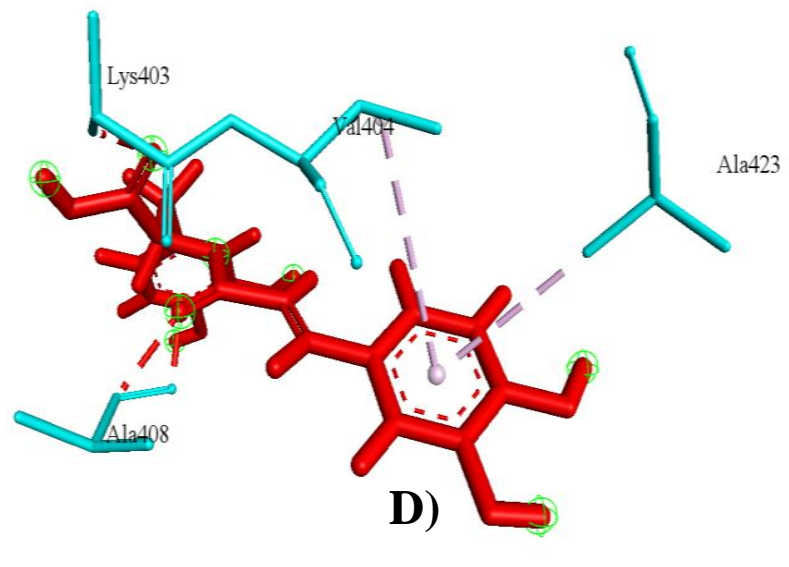

Figure 3: Ligand-Amino acid interaction mode of Chicoric acid with ZIKV Envelope protein A),Luteone with ZIKV Capsid Protein, Reserpine with ZIKV NS2B-NS3 protease C) and ZIKV NS5 RNA-dependent RNA polymerase protein with rosmarinic acid D). 


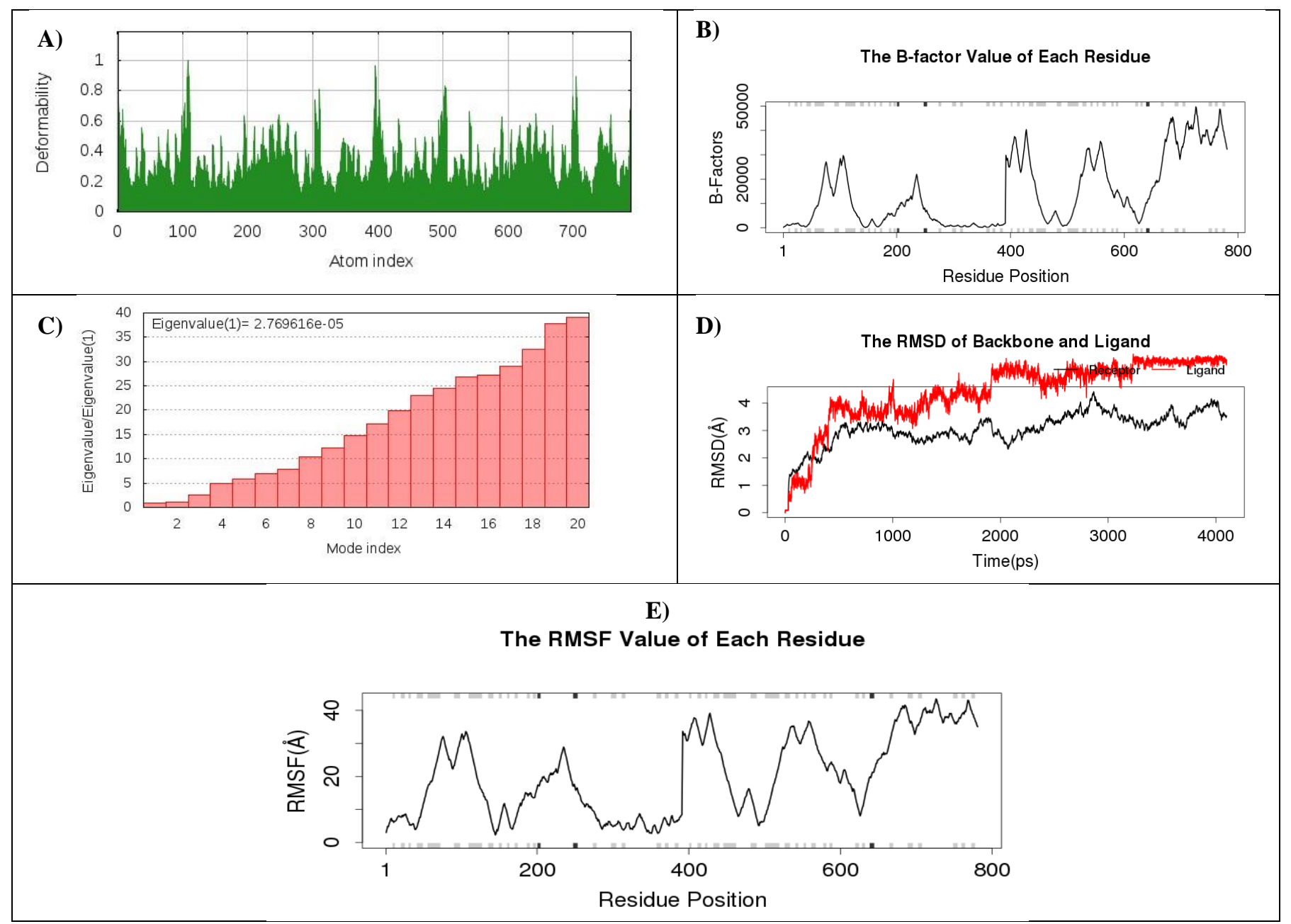

Figure 4: Molecular Dynamics of Envelope Protein-Chichoric acid complex: Deformability analysis A); B factor Analysis B); Eigen value C); RMSD plot D); RMSF value E). 


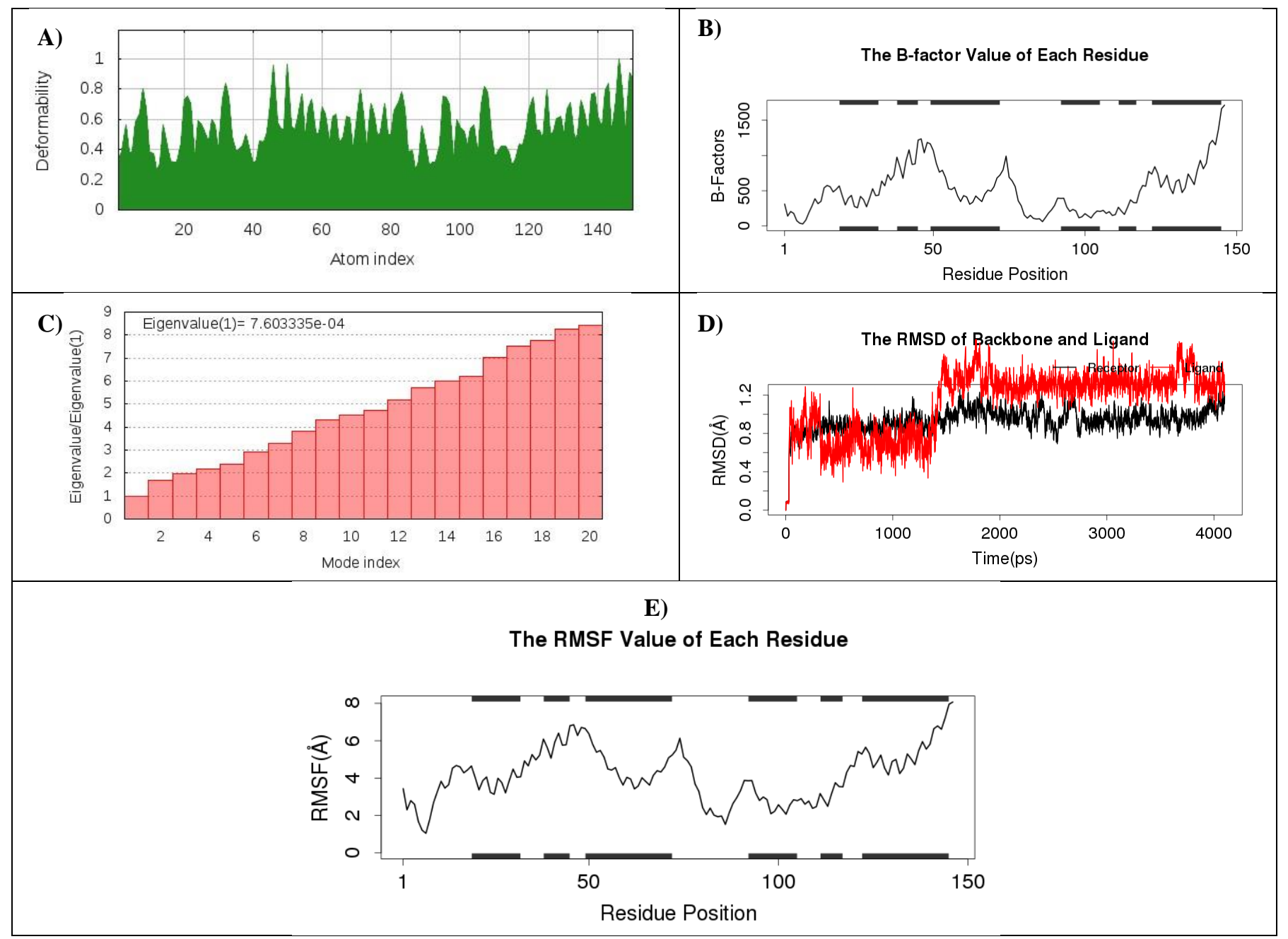

Figure 5: Molecular Dynamics of Capsid Protein-Luteone complex: Deformability analysis A); B factor Analysis B); Eigen value C); RMSD plot D); RMSF value E). 


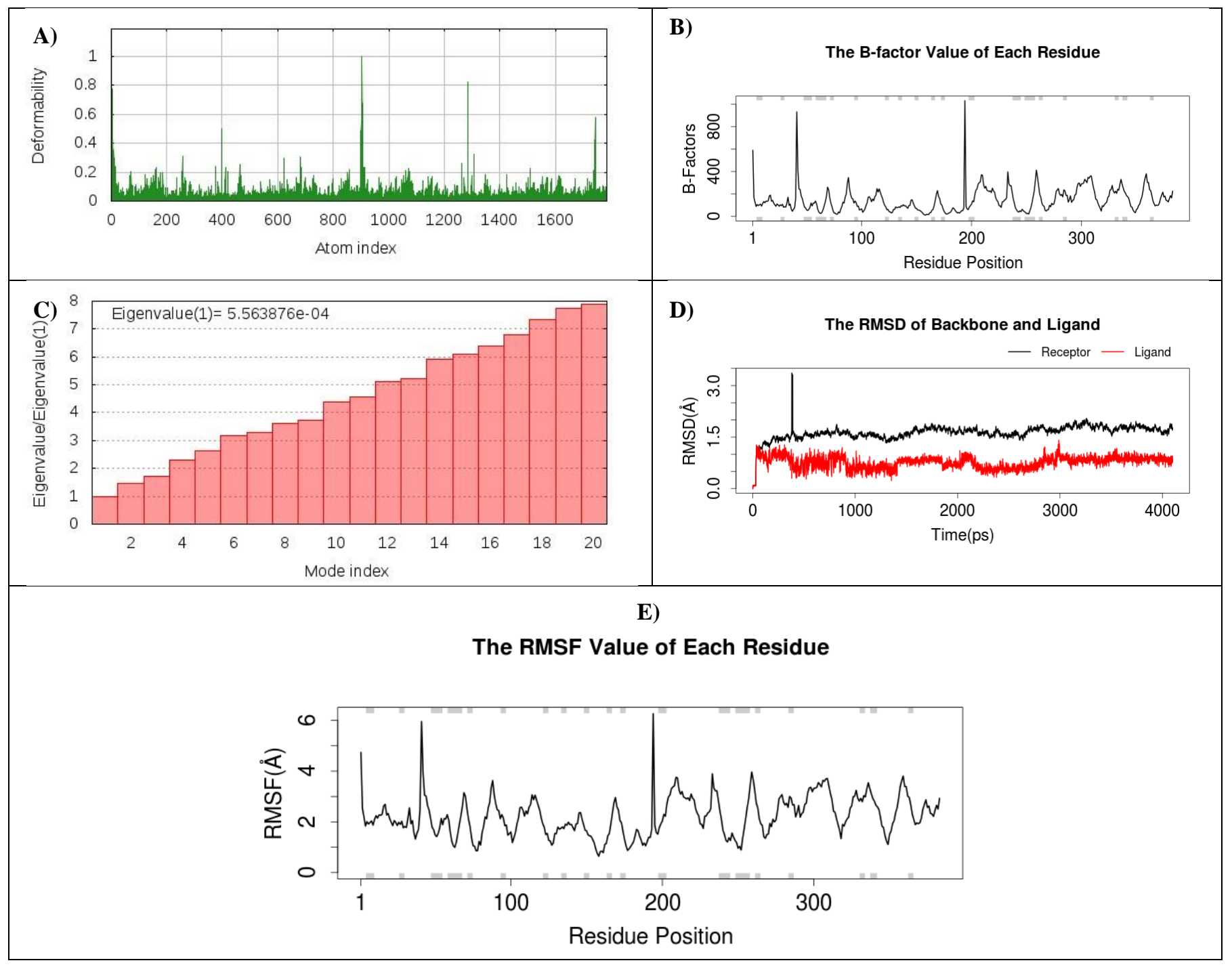

Figure 6: Molecular Dynamics of NS2B-NS3 Protease-Reserpine complex: Deformability analysis A); B factor Analysis B); Eigen value C); RMSD plot D); RMSF value E). 

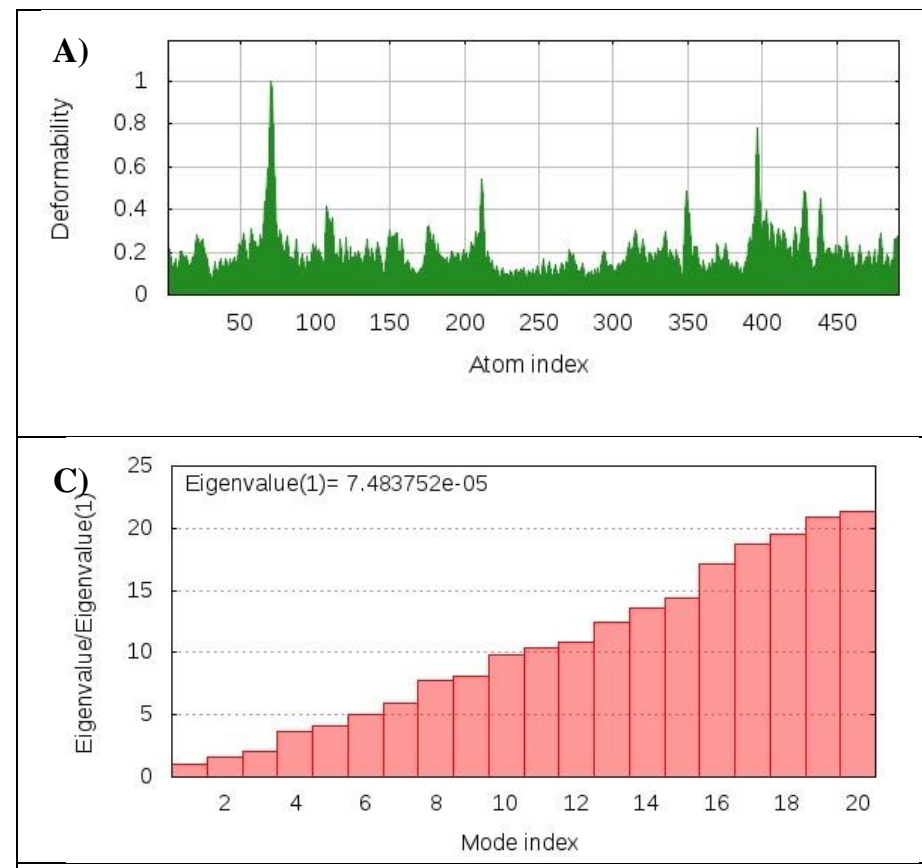

B)

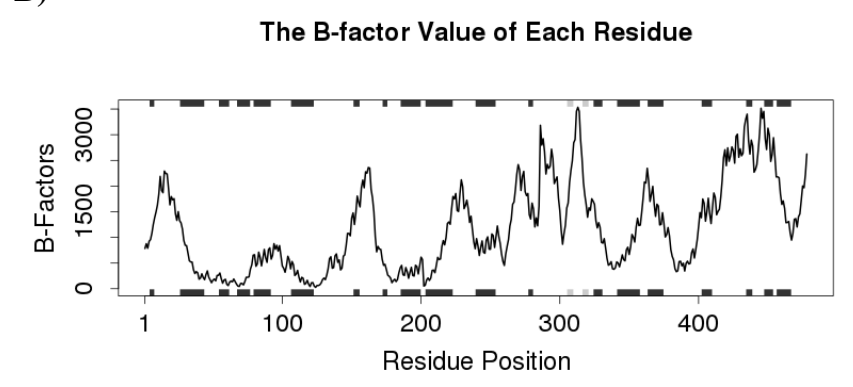

D)

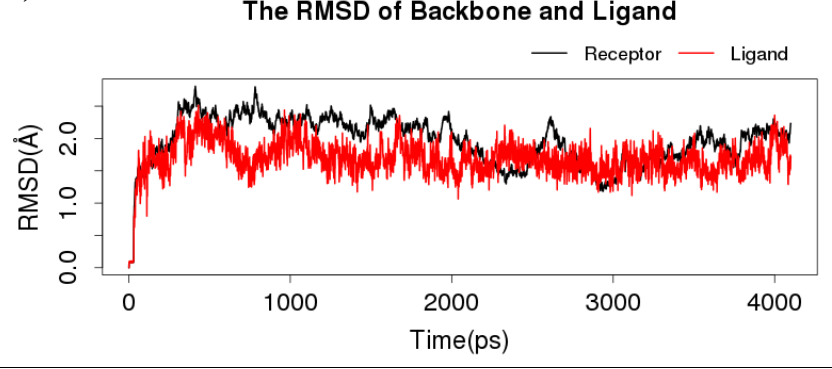

E)

The RMSF Value of Each Residue

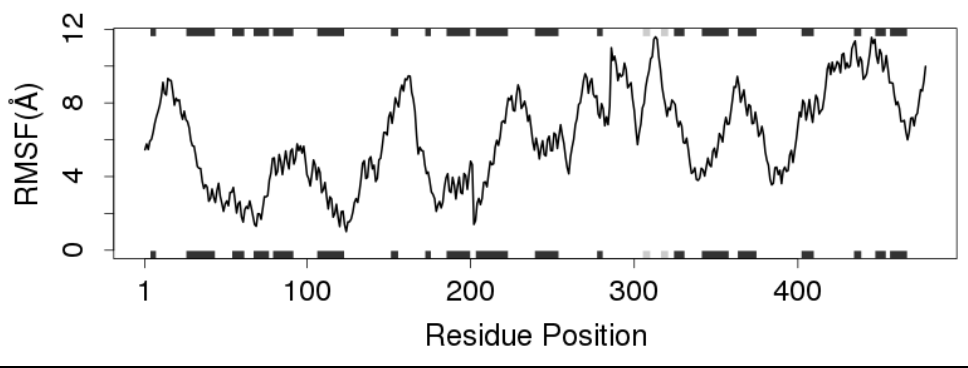

Figure 7: Molecular Dynamics of NS5 RNA-dependent RNA polymerase protein-Rosamarinic complex: Deformability analysis A); B factor Analysis B); Eigen value C); RMSD plot D);

RMSF value E). 


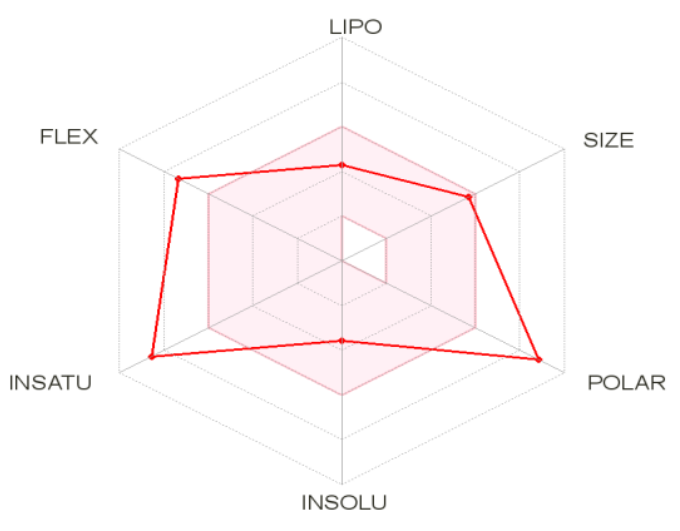

A)

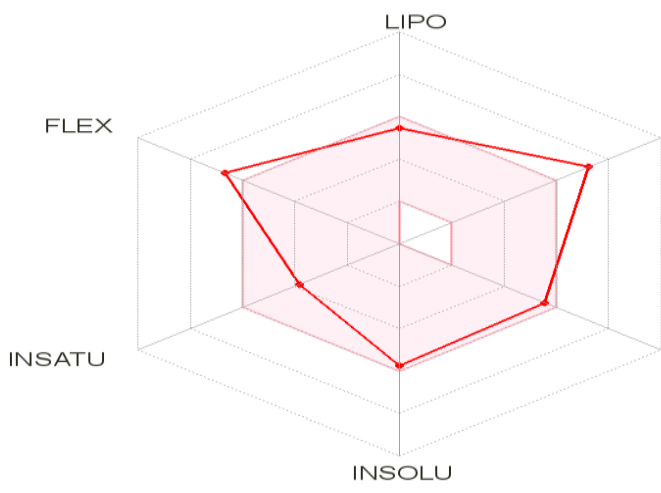

C)

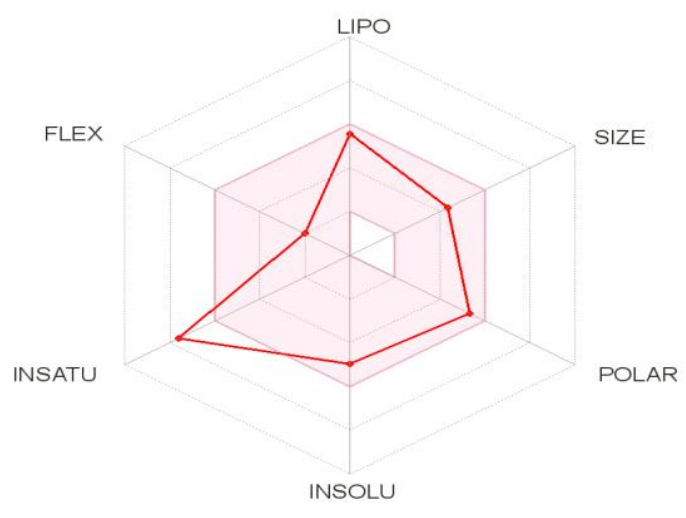

B)

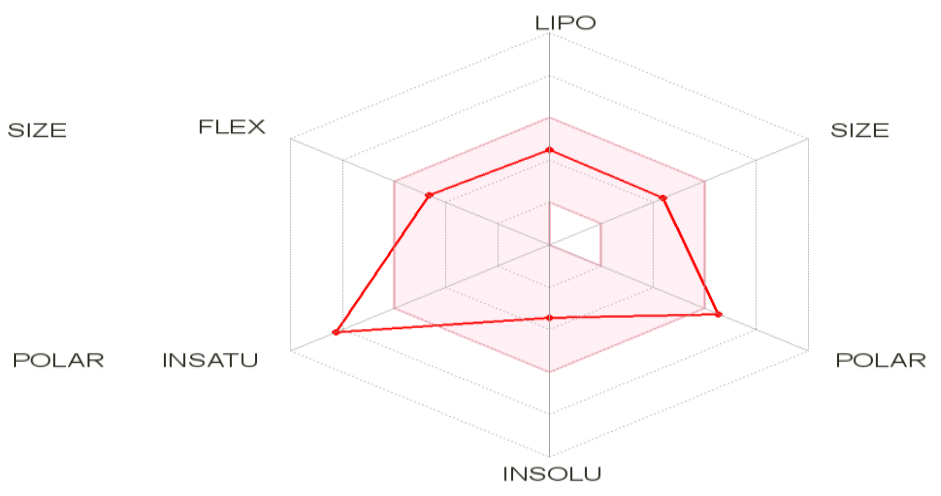

D)

Figure 8: ADME analysis of top four metabolites; Chicoric acid A), Luteone B), Reserpine C), and Rosmarinic acid D). 
bioRxiv preprint doi: https://doi.org/10.1101/2020.11.11.378083; this version posted November 12,2020 . The copyright holder for this preprint (which was not certified by peer review) is the author/funder, who has granted bioRxiv a license to display the preprint in perpetuity. It is made available under aCC-BY-NC-ND 4.0 International license.

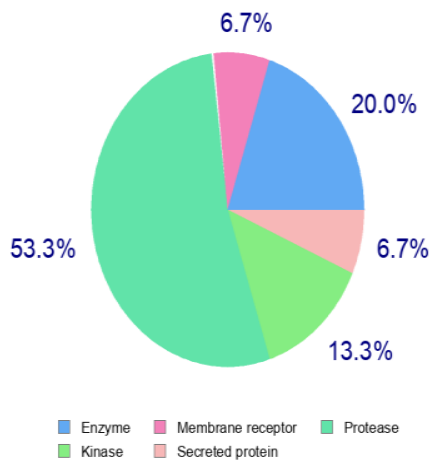

A)

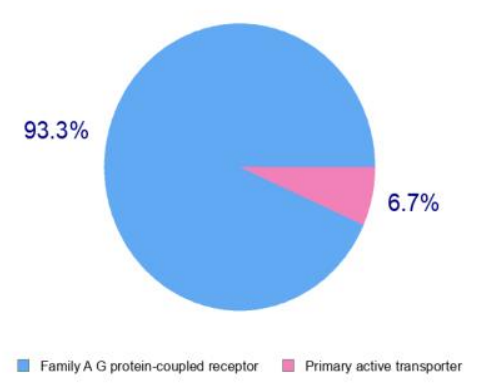

C)

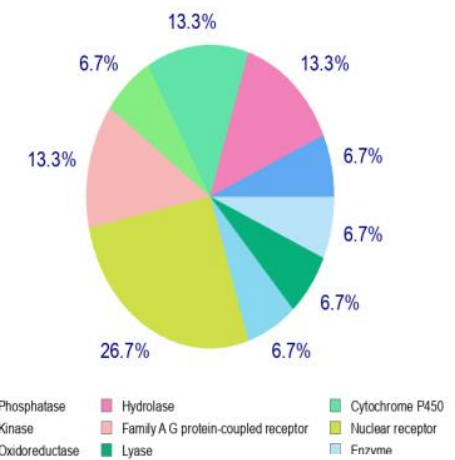

B)

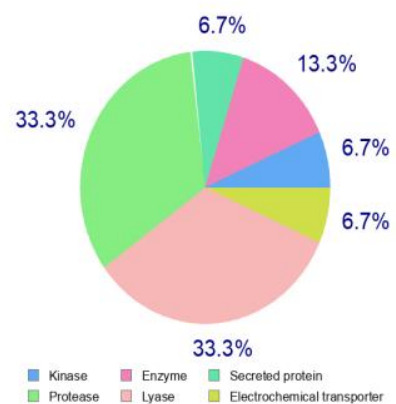

D)

Figure 9: Prediction of drug targets for Chicoric acid (A), Luteone (B), Reserpine (C) and Rosmarinic acid 